In the Wake of Lombard: The Reception of Augustine in the Early

\title{
Thirteenth Century
}

\author{
Eric Leland Saak \\ Indiana University-Purdue University Indianapolis
}

\begin{abstract}
This article investigates the new attitude toward the reception and use of Augustine in the early thirteenth century as seen in the works of Helinand of Froidmont and Robert Grosseteste. Both scholars were products of the Twelfth Century Renaissance of Augustine, represented in Peter Lombard's Sentences, the Glossa Ordinaria, and Gratian's Decretum. Yet both Helinand and Grosseteste reconstructed Augustine's texts for their own purposes; they did not simply use Augustine as an authority. Detailed and thorough textual analysis reveals that the early thirteenth century was a high point in Augustine's reception, and one which effected a transformation of how Augustine's texts were used, a fact [has] often been obscured in the historiographical debates of the relationship between "Augustinianism" and "Aristotelianism." Moreover, in point to the importance of Helinand's world chronicle, his Chronicon, this article argues for the importance of compilations as a major source for the intellectual and textual history of the high Middle Ages. Thus, the thirteenth century appears as the bridge between the Augustinian Renaissance of the Twelfth Century, and that of the Fourteenth, making clear the need for further research and highlighting the importance of the early thirteenth century for a thorough understanding of the historical reception of Augustine.
\end{abstract}

\section{Introduction}

The reception of Augustine is virtually synonymous with the intellectual history of the west. As such it has had its peaks and valleys. It is, however, a history that is still being written. ${ }^{1}$ Whereas scholars have revealed a renaissance of Augustine scholarship in the fourteenth century, ${ }^{2}$ the thirteenth century has not been seen as a major period in "Augustinianism," aside from the abstract, and ahistorical, dichotomy of Augustinianism and Aristotelianism in the high medieval schools. ${ }^{3}$ If we desire to understand the so-called late medieval Augustinian renaissance, we can only do so in context of that which came before, namely, the "pre-renaissance" reception of Augustine in the thirteenth century. A comprehensive treatment of

1. See The Oxford Guide to the Historical Reception of Augustine, ed. Karla Pollmann et al., 3 vols. (Oxford: Oxford University Press, 2013); hereafter cited as OGHRA.

2. See E. L. Saak, "The Augustinian Renaissance: Textual Scholarship and Religious Identity in the Later Middle Ages," in OGHRA 1:58-68.

3. E. L. Saak, "Augustine in the Western Middle Ages to the Reformation," in The Blackwell Companion to Augustine, ed. Mark Vessey (Oxford: Wiley-Blackwell, 2012), 465-477; for the term "Augustinianism," see E. L. Saak, "Augustinianism," in OGHRA 2:596-599.

This is the author's manuscript of the article published in final edited form as:

Saak, E. L., \& Philosophy Documentation Center. (2015). In the Wake of Lombard: The Reception of Augustine in the Early Thirteenth Century. Augustinian Studies, 46(1), 71-

104.http://doi.org/10.5840/augstudies201533110 
Augustine's reception in the thirteenth century is a lacuna in our understanding of Augustine's reception as such, yet it provides both the culmination of the twelfth-century reception of Augustine and the point of departure for later medieval developments leading into the Reformation. This present article hopes to illustrate the need to make the bridge between the "two Renaissances" and to provide a point of departure for further research.

A new approach to Augustine developed in the twelfth century, to the point that the twelfth century can legitimately be seen as the first "Augustinian Renaissance."4 The twelfth century as such stands as a watershed in the development of "the West." Since Charles Homer Haskins published his ground-breaking study, The Renaissance of the Twelfth Century, in 1927, initiating what has become known as the "revolt of the Medievalists," scholars have endeavored to reveal the impact of twelfth-century developments, demonstrating that much of what had been seen, and often still is, as unique to the later Italian Renaissance can already be found, at least in part, in the medieval humanism of the twelfth century. Even divorced from its "precursor" status, the "long twelfth century," extending from the later eleventh century on into the early thirteenth, was a period of intellectual, religious, social, economic, and political change of unprecedented scale. From the Gregorian reforms, the rise of the new monasticism, the crusades, and the emergence of papal monarchy, to the recovery of Aristotle and the new universities, Europe was being transformed, to the point that Giles Constable considered the twelfth century to have been a true Reformation, "a watershed in the history of the church and of Christian society as well as of monasticism and religious life."

Augustine played a major role in this Renaissance and Reformation, to the point that in the twelfth century, Augustine became omnipresent; as Dorothea Weber has claimed, the twelfth century was an aetas Augustiniana. ${ }^{6}$ Gratian's Decretum, Peter Lombard's Sentences, and the emerging Glossa ordinaria represent a high point in Augustine's reception and provided sufficient texts and references to the works of Augustine for less ambitious scholars to be able to appear learned in the thought of Augustine while never actually having read a complete text. Yet, according to the editor of the Sentences, Ignatius Brady, even Lombard himself had only read four texts of Augustine: De doctrina christiana (doctr. chr.), Enchiridion (ench.), De diuersis quaetionibus (diu.qu.) and the Retractationes (retr.), though he cited

4. E. L. Saak, The Impact of Augustine in the Later Middle Ages-From Lombard to Luther (Cambridge: Cambridge University Press, 2016, forthcoming).

5. Giles Constable, The Reformation of the Twelfth Century (Cambridge: Cambridge University Press, 1996), 325.

6. Dorothea Weber, "Confessiones," in OGHRA 1:167-174; 169. 
Augustine 719 times in the Sentences from a rather wide selection and made no less than thirty-five citations of the pseudo-Augustinian De fide ad Petrum and five citations of the pseudo-Augustinian Liber siue diffinitio ecclesiasticorum. Modern scholars attribute the latter to Gennadius, while Fulgentius of Ruspe is considered to have been the author of the De fide ad Petrum. ${ }^{7}$ This compares to the next most frequently cited authority in the Sentences, namely, Ambrose, whom Lombard cited 66 times. The majority of Lombard's Augustine citations were drawn from either the Glossa ordinaria or the Expositio of Florus of Lyons. ${ }^{8}$ Gratian's Decretum had a similar influence, and Augustine accounts for approximately $44 \%$ of the patristic sources. ${ }^{9}$ Yet not all of the Augustine citations in the Decretum are taken from genuine works of Augustine ${ }^{10}$ and, thus, the Decretum served likewise as a source for the continued spread of pseudo-Augustinian texts, which were viewed as authentic in the high and later Middle Ages. ${ }^{11}$ The Glossa ordinaria only became a set text on the entire Bible with the Rusch printed edition of $1480 .{ }^{12}$ The manuscript Glossa often circulated only in part, with the glosses on the various books of the Bible having been composed by different scholars. Augustine was a major patristic source, but not uniformly throughout. Augustine was the major influence on the Glossa for Genesis, for which, according to Ann Matter, De Genesi ad litteram (Gn. litt.)

7. Lombard cited Augustine 680 times in his Sentences, with an additional 34 quotations of the pseudo-Augustine's (i.e., Fulgentius de Ruspe's) De fide ad Petrum and five citations of the pseudoAugustine's (i.e., Gennadius's) Liber siue diffinitio ecclesiasticorum dogmatum, thus bringing the total of his Augustinian citations to 719. Cf. Jacques-Guy Bougerol, "The Church Fathers and the Sentences of Peter Lombard," in The Reception of the Church Fathers in the West. From the Carolingians to the Maurists, ed. Irena Backus (Leiden: Brill Academic Publishers, 1997), 1:113-164. On Fulgentius, see Chiara Ombretta Tommasi, "Fulgentius of Ruspe," in OGHRA 2:1022-1024.

8. Bougerol, "The Church Fathers," 115 (n.7). On Florus, see Cornelia Herbers, "Florus of Lyon," in OGHRA 2:1000-1002; for the Glossa, see Alexander Andrée, "Glossa ordinaria," in OGHRA 2:1055-1057.

9. Jean Werckmeister, "The Reception of the Church Fathers in Canon Law," in The Reception of the Church Fathers in the West, ed. Backus, 1:51-81; 66; Bruce C. Brasington, "Decretum of Gratian," in OGHRA 2:861-863.

10. Werckmeister "The Reception of the Church Fathers in Canon Law," 66 (n.9) noted that in the Decretum, "582 texts are attributed to Augustine, whereas only 469 are authentic."

11. Arnoud Visser, Reading Augustine in the Reformation. The Flexibility of Intellectual Authority in Europe, 1500-1620, Oxford Studies in Historical Theology (Oxford: Oxford University Press, 2011), 15, has noted: "Of all incunables published under Augustine's name, in fact, almost twothirds (116 out of 187) were suprious."

12. See Biblia Latina cum glossa ordinaria: facsimile reprint of the editio Princeps Adolph Rusch of Strassburg 1480/81, ed. Karlfried Froehlich and Margaret T. Gibson, 6 vols. (Turnhout: Brepols, 1992). 
"predominates and sets an exegetical tone," 13 though for the "mystical senses," "the sources are usually other than Augustine, and include selections from Isidore of Seville, the Venerable Bede and, occasionally, Jerome." ${ }^{14}$ Augustine also played a major role in the glosses on Deuteronomy, Joshua, Judges, Ruth, 1-4 Kings, 1-2 Chronicles, Ezra, Nehemiah, Tobit, Judith, Ester, and Psalms. He had relatively less influence for the other Old Testament books. For the New Testament, Augustine was important for the glosses on the Gospels of Mark, Luke, and John, together with Acts, but, surprisingly, was unimportant for both Paul's letters and the other books of the New Testament. ${ }^{15}$ Nevertheless, the Glossa ordinaria offered scholars substantial portions of Augustinian texts. So much so that Ann Matter could claim that, if we can come to an understanding of Augustine's appropriation for the Glossa, together with that of the other patristic authors, we will have gained the key for understanding "the secrets of the medieval Latin tradition of biblical exegesis." 16

These three texts represent a high point in Augustine's reception, forming the textual foundations, together with the recovery of Aristotle, of the origins of scholasticism. Yet, for the most part, in Lombard, Gratian, and the Glossa, Augustine was excerpted and used; he was not used as the textual foundation in any analytical sense. While Augustine was a normative authority, ${ }^{17}$ none of these authors went beyond the compilatory. However, in the later twelfth century and on into the thirteenth, we find a new attitude toward Augustine and his texts that would provide the basis for the new source erudition with respect to Augustine that is evident in the fourteenth-century Augustinian Renaissance. ${ }^{18}$ This new attitude is aptly illustrated by two case studies, the late twelfth and early thirteenth-century Cistercian, Helinand of Froidmont, and the Oxford scholar, Robert Grosseteste. While very distinct in terms of careers, Helinand and Grosseteste demonstrate a shift in Augustine's reception, contributing to the transition from the twelfth-century Augustinian Renaissance, to that of the later Middle Ages. If Lombard can be seen as the culmination of the earlier period of Augustine's reception, as in so many ways he was, then, in the wake of Lombard's achievement, we find in the early thirteenth

13. E. Ann Matter, "The Church Fathers and the Glossa ordinaria," in The Reception of the Church Fathers in the West, ed. Backus, 1:83-111; 86.

14. Ibid., 87.

15. Ibid., 88-108.

16. Ibid., 109; see also Andrée, “Glossa ordinaria," 1055-1057 (n.8).

17. On the issue of "normative authority," see Saak, The Impact of Augustine, forthcoming (n.4).

18. See also Richard Rouse and Mary Rouse, "Statim invenire: Schools, Preachers, and New Attitudes to the Page," in Authentic Witnesses. Approaches to Medieval Texts and Manuscripts (Notre Dame, IN: University of Notre Dame Press, 1991), 191-219. 
century the beginnings of a renewed reception of Augustine, the impact of which was to have far-reaching consequences.

\section{Helinand}

Not much is known about the life of Helinand. He was born around 1160 in the region of Beauvais, and died sometime after 1229. Of noble origin, Helinand studied with the pupil of Abelard, Ralph of Beauvais, and then pursued the life of a trouvere, before undergoing a conversion around 1182 and entering the Cistercian monastery at Froidmont. Helinand was the author of the well-known vernacular Les Vers de la Mort, and became a renowned preacher..$^{19}$ Moreover, in the early thirteenth century, Helinand set his hand to composing an encyclopedic world chronicle, his Chronicon.

While Romance literature offered social commentary on the author's contemporary world, encyclopedic literature attempted to present a summation of knowledge. There was, however, no single genre or form of encyclopedic literature. What unified medieval "encyclopedias" was the compilatory nature of the work. Universal chronicles formed a genre of encyclopedic literature that sought to present an interpretation of and commentary on the past for the author's or compiler's present in attempt to preserve knowledge. As the thirteenth-century chronicler Guillaume de Nangis stated in the prologue to his Chronicon:

Since the deeds of times past are infinite and there are very many recorders of history indeed, so that they are not able to be had or read by all, it is not in vain that I have taken charge to collect together a few things from the infinite and to bring them together into one compendium which is prepared and completed for the pleasure of its readers. ${ }^{20}$

After discussing his approach, and how he would draw from Jerome's translation of Eusebius for the history of the earliest times, as well as from Sigibert of Gembloux for the later, Guillaume announced that he would add other things to these accounts, which, even if recorded by others, he would compose in a new order and way, and

19. For Helinand's life, see F. Wulff and E. Walberg, eds., Les Vers de la Mort par Hélinant, Moine de Froidmont (Paris: Firman Didot et cie, 1905), iii-xxvii. See also "Helinand of Froidmont Bibliography," A Vincent of Beauvais website, http://www.vincentiusbelvacensis.eu/helinand/hfbib .htm, and "Hélinand de Froidmont," Arlima, http://www.arlima.net/eh/helinand_de_froidmont .html, both of which give extensive bibliography on Helinand.

20. Guillaume de Nangis, Chronicon, Paris, BnF MS lat. 4917, fol. 1': "Cum infinita sunt temporum gesta gestorumque digestores quam plurimi nec possint ab omnibus uel haberi uel legi non inutiliter duxi ex infinitis pauca colligere et in unum coartare compendium que legentibus oblectamentum pariant et profectum." 
that he would also compile other things from his own time. ${ }^{21}$ Thus, for Guillaume, the past was to be preserved and brought "up to date" by the compilation of a compendium of knowledge for the enjoyment and education of his audience. It was this aspect of the universal, world chronicle that led Jacques Le Goff to consider the universal chronicle as the "model encyclopedia for history."22

The thirteenth century was the height of medieval encyclopedic endeavors. That era saw the compilation of such classic medieval encyclopedias as the Dominican Thomas of Cantimpré's Liber de natura rerum (1230-1245), the Franciscan Bartholomeus Anglicus's De proprietatibus rerum (1242-1247), and the Dominican Vincent of Beauvais's Speculum maius (1250). ${ }^{23}$ Yet, before these classic works appeared, that is, during the years 1211-1223, precisely the period in which vernacular historiography in France began to flourish, ${ }^{24}$ Helinand set his pen to writing a compilatory world chronicle in Latin, which became a major source for Vincent of Beauvais's Speculum Maius, ${ }^{25}$ and represents what Le Goff called the "encyclopedic spirit" of the later twelfth and early thirteenth century. Moreover, scholars have repeatedly emphasized the importance of the Cistercians for the intellectual history of the period that is often-albeit inadequately-labeled "early scholasticism." ${ }^{26}$ Thus Helinand's Chronicon is an invaluable source for intellectual life in the early thirteenth century: it is a window onto a world that is often ignored, caught as it is between the more attractive themes of St. Bernard on the one end, and the rise of the universities on the other. Helinand's Chronicon is a sort of map of this terra incognita and, as such, has much to tell us not only about medieval historiography,

21. Ibid.: "Cetera autem ego frater Gwillelmus sancti Dyonisii in Francia monachus subiungens que ab aliis quidem digesta erant sed non eodem modo ordinata composui, et alia mei temporis compilaui."

22. See Jacques Le Goff, "Pourquoi le XIII' siècle a-t-il été plus particulièrement un siècle d'encyclopédisme?" in L'enciclopedismo medievale, ed. M. Picone (Ravenna: Longo, 1994), $23-40$.

23. See E. L. Saak, "Vincent of Beauvais," in OGHRA 3:1860-1862.

24. See G. Spiegel, Romancing the Past. The Rise of Vernacular Prose Historiography in ThirteenthCentury France (Berkeley: University of California Press, 1993).

25. See E. R. Smits, "Vincent of Beauvais: A Note on the Background of the Speculum," in Vincent of Beauvais and Alexander the Great: Studies on the "Speculum Maius" and its Translations into Medieval Vernaculars, ed. W. J. Aerts, E. R. Smits, and J. B. Voorbij (Groningen: E. Forsten, 1986), 1-9.

26. See, for example, Jean Leclercq, The Love of Learning and the Desire For God. A Study of Monastic Culture (New York: Fordham University Press, 1982), 196-228; Richard Rouse and Mary Rouse, "The Development of Research Tools in the Thirteenth Century," Authentic Witnesses, 221-255; 226 (n.18); Martha G. Newman, The Boundaries of Charity. Cistercian Culture and Ecclesiastical Reform, 1098-1180 (Stanford: Stanford University Press, 1996). 
but also about the creation, functions and uses of texts in the high Middle Ages, including those of Augustine.

One of the major challenges facing the interpreter of Helinand's Chronicon is that of interpreting medieval compilations as such, whereby the majority of the words present in the Chronicon are excerpted from other scholars. ${ }^{27}$ Helinand's Chronicon is highly intertextualized. Consonant with medieval grammatical culture, it forms a textual pastiche, whereby, in the words of Martin Irvine, "the resulting collection forms an interpretive arrangement of texts." ${ }^{28}$ The interpretative nature of the Chronicon, however, surpasses that of mere emplotment. Delisle argued:

Hélinand belonged to a school which had for a principle not to confuse original parts of an account with borrowings added on to the more ancient authors. He held to the rule to cite his authorities and he took care to place the word auctor at the beginning of phrases or paragraphs for which he would take responsibility. ${ }^{29}$

Yet, on closer investigation, Helinand's Chronicon appears very different from Delisle's description. The auctor notation, pace Delisle, appears in the text as a scribal designation rather than as an authorial self-identification, thus testifying to Seán Burke's statement that "text and author are united under the signs of their disunion." ${ }^{30}$ No rule for citing authorities can be found that systematically and clearly differentiates between Helinand's own words and those of his sources. Moreover, Helinand nowhere spoke of the gesta temporum, and whereas Guillaume de Nangis, Vincent of Beauvais, Bartholomeus Anglicus, and Thomas of Cantimpré all described their own works as compilations and their own activity as one of compiling, Helinand used other verbs. It is not the verb compilare that Helinand used, but adnotare, excerpere, excipere, explicare, exponere, and tractare.

27. See E. L. Saak, "The Limits of Knowledge: Hélinand de Froidmont's Chronicon," in Pre-modern Encyclopedic Texts. Proceedings of the Second COMERS Congress, Groningen, 1-4 July 1996, ed. Peter Binkley, Brill's Studies in Intellectual History 79 (Leiden: Brill Academic Publishers, 1997), 289-302.

28. M. Irvine, The Making of Textual Culture. 'Grammatica' and Literary Theory, 350-1100 (Cambridge: Cambridge University Press, 1994), 428.

29. L. Delisle, "La chronique d'Hélinand moine de Froidmont," Notices de documents publiés pour la Société de l'Histoire de France 40 (1884): 141-154; 142: "Hélinand appartient à une école qui avait pour principe de ne pas confondre les parties originales du récit avec les emprunts faits à des auteurs plus anciens. Il s'est imposé la règle de citer ses autorités, et il a tenu à mettre le mot Auctor au commencement des phrases ou des paragraphes dont il prenait directement la responsabilité."

30. S. Burke, The Death and Return of the Author. Criticism and Subjectivity in Barthes, Foucault and Derrida (Edinburgh: Edinburgh University Press, 1992), 6; cf. S. Burke, Authorship. From Plato to the Postmodern. A Reader (Edinburgh: Edinburgh University Press, 1995). 
In short, Helinand's Chronicon stands at the beginnings of a development in medieval literary theory of compilatio whereby "to compile" underwent a change in the later thirteenth and fourteenth century from a derogatory description of someone else's work to a proud self-designation of writers' own activity as being one not of narration but of compilation. ${ }^{31}$

Helinand's Chronicon is a historical work that seeks to re-emplot, by means of the textual power exerted in the mode of compilation, ${ }^{32}$ the textual traditions of the received historia in keeping with a Cistercian religious program. ${ }^{33}$ This program was designed to educate Cistercians in the best knowledge of the day, including natural philosophy, biblical scholarship, and theology, to combat heresy in society (such as the Cathars) and dangerous approaches to knowledge that were being followed in the new universities. Helinand's Chronicon is a Cistercian "textbook" that reveals the religious and intellectual climate of late twelfth and early thirteenth-century Europe, when the Cistercian Order was struggling to maintain its religio-political dominance in the face of the challenges posed by the rise of the universities and the newly established Franciscan and Dominican Orders. Helinand's on-going endeavor to construct his work is evident by the "genre-bending" of the text, whereby it assumes the form at times of a biblical commentary, at times of a catalogue of exempla for preaching (and indeed Helinand in places incorporated his own sermons into his Chronicon), and at other times that of a formal academic treatise. Hence its encyclopedic nature and its scope. It thus serves as an excellent case study for the reception and use of Augustine in encyclopedic literature.

By the time Helinand began to write his Chronicon, he had a vast store of Augustinian material at his disposal, one that far surpassed the early medieval florilegia, such as Prosper of Aquitaine's Sententiae and Eugippius's Excerpta ex operibus s. Augustini ${ }^{34}$ In some ways, this fact gets at the central problem: Lombard's Sentences, Gratian's Decretum, and the Glossa were themselves compilations, and, when seen as such, should put Helinand's endeavor in broader perspective than when Helinand is viewed simply as an exceptor who was intent on putting together a medieval encyclopedic text. One of the defining characteristics of the fourteenth-century Augustinian renaissance was the source erudition with respect to Augustine's works, whereby scholars, predominately but not exclusively members of the OESA, were

31. See A. J. Minnis, Medieval Theory of Authorship: Scholastic Literary Attitudes in the Later Middle Ages, 2nd ed. (Aldershot: Wildwood, 1988).

32. Saak, "The Limits of Knowledge," 289-302 (n.27).

33. See Newman, The Boundaries of Charity (n.26).

34. For Prosper, see David Lambert, "Prosper of Aquitaine," in OGHRA 3:1605-1610; for Eugippius, see Alfons Fürst, "Eugippius," in OGHRA 2:954-959. 
no longer satisfied with the florilegia and compilations, but went back ad fontes to the originalia Augustini, as the library of the Sorbonne labeled one of its benches based on the inventory of 1275 , even though 32 of the 149 books there listed are Pseudo-Augustine. ${ }^{35}$ Consequently, the question we must ask is to what extent did Helinand represent the impact of the twelfth-century Augustinian renaissance, and to what extent did he take the tradition further, harkening the analogous renaissance that would begin a century after Helinand's death? Or, in other words, was Helinand's reliance on Augustine based on his compiling or excerpting from other compilations, or was it based on his own reading of Augustine's works themselves?

In book 47 of the Chronicon, under the year 1083, we fi an indicative reference. Here Helinand was inserting passages from the Chronica of Sigibert of Glemboux and Guillemus de Nangis. Helinand had drawn from Sigibert to relate the miraculous testimony of various birds to the sanctity of Anselm of Lucca, which then included the citation of Augustine's De ciuitate dei (сіи.) 3.23 as a supporting authority that related a similar event. ${ }^{36}$ Yet the quotation from Augustine was not present in Si-

35. E. L. Saak, Creating Augustine. Interpreting Augustine and Augustinianism in the Later Middle Ages (Oxford: Oxford University Press, 2012), 31.

36. Helinand, Chronicon 47 (PL 212: 977C-D): "Sigebertus. Anselmus Lucensis episcopus Hildebrandi cooperator indefessus, apud Mantuam exsulans moritur, qui in Ieremiam et in Psalmos tractatus edidit; et doctrinam Hildebrandi libro luculento confirmauit. Cujus sanctitas miraculis declarata est. Domesticae aues, pauones, galiinae et anseres a domibus se extraneantes, omnes fiunt syluaticae. Augustinus, in lib. III De ciuitate Dei, simile portentum narrat contigisse, dicens: 'Antequam se aduersus Romam sociale Latium commoueret, omnia animalia humanis usibus subdita, canes, equi, asini, boues, et quaecunque alia pecora sub hominum dominio erant, subito efferata, et domesticae lenitatis oblita, relictis tectis libera uagabantur; et omnem non solum alienorum, uerum etiam dominorum auersabantur accessum; nec sine exitio uel periculo audentis, si quis de proximo urgeret. Quanti mali signum fuit, si hoc signum fuit; quod tantum malum fuit, si etiam signum non fuit."; Sigebertus, Chronica (PL 160: 223B), under year 1086: "Anselmus Lucensis episcopus, Hildibrandi papae cooperator indefessus, apud Mantuam exulans moritur; qui in Hieremiam et in Psalmos tractatus edidit, et doctrinam Hildibrandi libro luculento confirmauit; cuius sanctitas miraculis declarata est. Domesticae aues, pauones, gallinae et aucae, a domibus se extraneantes, fiunt siluaticae."; ciu. 2.23 (PL 41: 104): "Sed iam illa mala breuiter, quantum possumus, commemoremus, quae quanto interiora, tanto miseriora exstiterunt: discordiae ciuiles, uel potius inciuiles; nec iam seditiones, sed etiam ipsa bella urbana, ubi tantus sanguis effusus est, ubi partium studia, non concionum dissensionibus uariisque uocibus in alterutrum, sed plane iam ferro armisque saeuiebant: bella socialia, bella seruilia, bella ciuilia quantum Romanum cruorem fuderunt, quantam Italiae uastationem desertionemque fecerunt? Namque antequam se aduersus Romam sociale Latium commoueret, cuncta animalia humanis usibus subdita, canes, equi, asini, boues, et quaeque alia pecora sub hominum dominio fuerunt, subito efferata et domesticae lenitatis oblita, relictis tectis libera uagabantur, et omnem non solum aliorum, uerum etiam dominorum auersabantur accessum, non sine exitio uel periculo audentis, si quis de proximo urgeret. Quanti mali signum fuit, si hoc signum fuit quod tantum malum fuit, si etiam signum non fuit? Hoc si nostris temporibus accidisset, rabidiores istos quam illi sua animalia pateremur." 
gibert; it was a reference Helinand supplied himself. Nor can the citation be traced to any other intermediate source, at least insofar as I have been able to discover. Helinand was supplying the additional authority based on his own knowledge of ciu. and he cited his source accurately, though without giving the chapter number.

That Helinand had a firsthand knowledge of ciu. is beyond question, and a thorough knowledge at that; Helinand knew the text forwards and backwards, as evidence by his reconstructing the text of ciu. in book 2, chapters 60-71 of his Chronicon.${ }^{37}$ Here Helinand included a long digression on the nature of angels and demons, drawing most of all on Augustine. Chapters 48 through 71 form a continuous line of argument, constructed from ciu. 8-10. Continuous indeed, but it is so not simply following along copying Augustine's text; rather, Helinand "cuts and pastes" his source to create a new order and line of argument, in short, he creates a new text, much as a collage or a quilt is a new work made from old materials. In chapter 60 Helinand begins with ciu. 10.2, then moves in chapter 61 to ciu. 10.26. In chapter 62 he begins with summarizing ciu. 9.7, before moving then back to book 10 and chapter 21 . He continues with 10.21 at the beginning of chapter 63 , right where he had left it, more or less, and continues in this fashion, following fairly closely Augustine's text up until chapter 66, where we find a prime example of "cut and paste." In chapter 66, Helinand begins with ciu. 10.23 for the first phrase of his first sentences, before then summarizing 6 lines of Augustine with six words, and then includes an insert of the Greek patricum noym from ciu. 10.28. But then Helinand continues. Still working on chapter 66, he then moves from ciu. 10.23 to 10.24 , but then, after a direct quote of two lines, Helinand continues by summarizing the nine lines of Augustine that immediately preceded the one he had just quoted, working backwards in Augustine's text, so to speak. He then returns to direct quotation where he had been before his inverted insert, and continues in a "forward" direction following Augustine's text through chapter 67, before jumping to $c i u$. 10.27 in chapter 68 . Then he continues along with 10.28 and 10.29 , before jumping back with no warning in the middle of chapter 68 to ciu. 10.9, which then continues in chapter 69 through chapter 71, except for the fact that Helinand once again works "backwards" in chapters 70 and 71, citing increasing earlier parts of ciu. 10.9. Clearly, Helinand is creating a new text here, one pieced together from Augustine. In no way is he "simply" copying Augustine. Such a composite text cannot be attributed to the manuscript tradition of ciu., nor is such an arrangement extant in the florilegia. One can only conclude that Helinand was constructing

37. For further details, cf. the Appendix to this article. 
his text from scratch, so to speak, and he did so based on a thorough and intimate knowledge of ciu. $^{38}$

In his sermons, Helinand appealed to Augustine less frequently than he did in his Chronicon. Nevertheless, it appears that, for the most part, when he did so Helinand was citing Augustine directly. In sermo 7, Helinand cites Contra Faustum (c. Faust.) twice, the first time from c. Faust. 17.6 and the second, from 19.13. ${ }^{39}$ While $c$. Faust. was a well-known text and often excerpted, circulating not only in complete manuscripts but also in condensed versions, ${ }^{40}$ these two specific passages are extremely rare.C.Faust. 17.6 was not excerpted; it seems that Helinand's citation is the first (medieval) citation of this passage. ${ }^{41}$ C. Faust. 19.13 was likewise rarely cited; it is found only in Helinand, William of St. Thierry, and Florus of Lyon. ${ }^{42}$

38. I have searched extensively for some source of Helinand's Augustine text, esp. during my work on the edition of Heliannd's Chronicon at the University of Groningen with C. H. Kneepkens. It is certainly possible that somewhere "out there" there is a particular manuscript that Helinand used with such an ordering of ciu. I simply have not found it yet. Still, I would be very surprised if such a manuscript existed. This arrangement of texts from ciu. cannot have been due to a faulty scribe, or a faulty text; it was not simply scribal error, but a willful, planned construction. The same applies to the text of Grosseteste below, even though I have spent far more time searching for Helinand's source.

39. Helinand, Sermo 7 (PL 212: 536D, 542A).

40. N. Baker-Brian, "Contra Faustum," in OGHRA, 1: 196-203.

41. Helinand, serm. 7 (PL 212: 536D): "Unde dicit: Non ueni soluere legem, sed adimplere. Super quem locum Augustinus contra Faustum. Ille adimplet legem, qui sic uiuit, ut praecipit lex: plenitudo enim legis est charitas. Impletur ut praecepta sunt; uel cum exhibentur, quae ibi prophetata sunt."; c. Faust. 17.6 (PL 42: 344): "Istam charitatem Dominus et exhibere et donare dignatus est, mittendo fidelibus suis Spiritum sanctum. Unde item dicit idem apostolus: Charitas Dei diffusa est in cordibus nostris per Spiritum sanctum qui datus est nobis. Et ipse Dominus: In hoc scient omnes quia discipuli mei estis, si uos inuicem diligatis. Impletur ergo lex, uel cum fiunt quae ibi praecepta sunt, uel cum exhibentur quae ibi prophetata sunt."

42. Helinand, serm. 7 (PL 212: 542A-B): "Christus itaque redemit nos ab onere legis Mosaicae, quando ritum caeremoniarum legalium de medio tulit, et sacramenta nouae legis instituit, uirtute, ut ait Augustinus, maiora, utilitate meliora, actu faciliora, numero pauciora; tanquam iustitia fidei iam reuelata."; c. Faust. 19.13 (PL 42: 355): "Proinde prima sacramenta, quae obseruabantur et celebrabantur ex Lege, praenuntiatiua erant Christi uenturi: quae cum suo aduentu Christus impleuisset, ablata sunt; et ideo ablata, quia impleta; non enim uenit soluere Legem, sed adimplere: et alia sunt instituta uirtute maiora, utilitate meliora, actu faciliora, numero pauciora, tanquam iustitia fidei reuelata, et in libertatem uocatis filiis Dei iugo seruitutis ablato, quod duro et carni dedito populo congruebat."; Florus of Lyon, De Expositione Missae, 4 (PL 119: 20C-D): "Proinde prima sacramenta, quae obseruantur et celebrantur ex lege, praenuntiatiua erant Christi uenturi, quae cum suo aduentu Christus impleuisset, oblata sunt; et ideo oblata quia impleta, non enim uenit soluere legem sed adimplere. Alia sunt instituta uirtute maiora, utilitate meliora, actu faciliora, numero pauciora, tanquam iustitia fidei reuelata, et in libertate uocatis filiis Dei iugo seruitutis ablato, quod duro et carni dedito populo congruebat, qualia sunt in Ecclesia baptismus 
Moreover, in the same sermon, Helinand cited from $s .187$, followed by a further citation to $s .136 .{ }^{43}$ Helinand is also the first author to cite these two passages; they were not previously excerpted. Thus Helinand could only have cited these passages if he had access to the text itself.

Such examples as the ones given above could easily be multiplied. I have not, however, checked every Augustine citation in Helinand's works, and there are certainly cases when Augustine is cited because it is in the source Helinand was excerpting, such as in book three, chapter twenty where Helinand simply "cut and pasted" from Lombard's Sentences ${ }^{44}$ Yet the evidence is clear that Helinand had a

Christi, eucharistia Christi, signaculum Christi."; William of St. Thierry, Expositio in Epistolam ad Romanos, 3.27 (PL 180: 580D): "Lex uero factorum, est lex sancta, et mandatum sanctum, et iustum, et bonum; sed per cuius bonum peccatum operatur mortem, prohibens et faciens omnem concupiscentiam; imperans et non adiuuans, puniens nec liberans. Habet autem lex fidei instituta quaedam in sacramentis Ecclesiae, legis factorum sacramentis actu faciliora, utilitate meliora, uirtute maiora, numero pauciora; tanquam iustitia fidei reuelata, et in libertatem uocatis filiis Dei, et iugo seruitutis ablato, quod duro et carni dedito populo congruebat." Helinand could not have taken his reference from William and neither William nor Florus cited Augustine. It is certainly possible, however, that if Helinand had indeed been using Florus, the reference to Augustine could have been given in the margin. Yet the editors of the text in Migne do not give any indication of the source. Thus, it seems most likely indeed that Helinand drew from the text of $c$. Faust. itself, especially in light of his citation of c. Faust.17.6.

43. Helinand, Sermo 7 (PL 212: 539C): "Vnde Augustinus homilia de Incarnatione Domini: 'Tantum te pressit humana superbia, ut te non posset, nisi humilitas subleuare diuina.' Idem in alia de eodem: 'Hinc intelligimus, quam graues aestimet apud se Deus noster humanorum criminum causas, propter quas non angelum, non archangelum, sed Deum misit ad terras.' Et addit: 'Quam grauis sit peccati, et quam dura conditio, prodit remedii magnitudo; quanta malorum discussio erit, qua damnabuntur, sollicitudo indicat, qua redimuntur."'; s. 187.3.3 (In Natali domini V) (PL 38: 1004): "Tantum te pressit humana superbia, ut te non posset nisi humilitas subleuare diuina."; s. 136.3 (In Epiphania domini VI) (PL 39: 2014): "Et ille quidem pretiosum sibi esse hominem pretii ipsius dignitate perdocuit, ut hinc quoque intelligamus quam grandes apud se aestimet Deus noster humanorum criminum causas, propter quas non angelum, non archangelum, sed Deum misit ad terras; quam grauis sit peccati et quam dura conditio, prodit remedii magnitudo."

44. The following is from the Vatican ms of Helinand's Chronicon, with the rubricized marginals printed in bold, and references to Lombard given in brackets. Lombard is cited according to Petri Lombardi, Sententiae In IV Libris Distinctae, 2 vols. ed. Ignatius Brady, v. 1 (Grottaferrata: Editiones Collegii S. Bonaventurae ad claras aquas, 1971):

“*Augustinus in libro De duabus animabus* Augustinus in libro De duabus animabus: Uoluntas est animi motus cogente nullo ad aliquid non admittendum uel adipiscendum. Hec autem ut non admittat malum uel adipiscatur bonum, preuenitur et preparatur gratia Dei. [Lombard 2 Sent. 26.2.1-2 (ed. Brady, 471.15-20)] *Augustinus in libro Enchiridion* Unde Apostolus utramque gratiam commendans, preuenientem et subsequentem, idest operantem et cooperantem, uigilanter dixit: Non est uolentis neque currentis sed miserentis Dei. Nam si ut quibusdam placet quod dictum est, ita accipiatur tanquam diceretur, non suffi sola uoluntas hominis, si non sit etiam misericordia Dei eadem ratione econtrario posset dici non est miserentis Dei sed uolentis hominis cum 
thorough knowledge of selected texts of Augustine ${ }^{45}$ which he then put to his own particular use. ${ }^{46}$ In this light, Helinand's erudition with respect to Augustine matched

non suffi misericordia Dei si non sit uoluntas hominis. Homo enim credere uel sperare non poterit nisi uelit nec peruenire ad palmam nisi uoluntate currat. Restat ergo ut ideo recte dictum intelligatur ut totum detur Deo qui hominis uoluntatem bonam et preparat adiuuandam et adiuuat preparatam. [Ibid.,26.2.2(ed. Brady, 471.20-472.10)] *Augustinus ad Bonefacium* Nolentem preuenit ut uelit, uolentem subsequitur ne frustra uelit. Igitur uoluntas comitatur gratiam, non ducit, pedissequa est, non preuia. [Ibid., 26.2.3 (ed. Brady, 472.20-21)]. *Augustinus in libro De libero arbitrio et in libro Retractationum* Tria quippe sunt genera bonorum: magna, media, minima. Uirtutes quibus recte uiuitur, magna bona sunt, species quorumlibet corporum sine quibus recte uiui potest, minima; potentie animi sine quibus recte uiui non potest, media. Primis bonis nemo male utitur. Ceteris, idest minimis et mediis, et bene et male uti possumus. [Cf. Ibid. 26.10 (ed. Brady, 479.2-13)] *Augustinus in libro De libero arbitrio* In mediis bonis continetur liberum uoluntatis arbitrium, quia et male illo uti possumus, sed tamen tale est ut sine illo recte uiuere nequeamus. Bonus autem usus eius iam uirtus est que de bonis magnis est quibus male uti nullus potest. [Ibid. 26.11.1 (ed. Brady, 479.17-19)] *Quid est uirtus* Uirtus autem est bona qualitas mentis qua recte uiuitur et qua nullus male utitur, quam Deus solus in homine operatur. [Ibid. 27.1.1 (ed. Brady, 480.8-10)] *Augustinus super psalmum* Cum autem dicit propheta ex persona ecclesie: feci iudicium et iusticiam, non ipsam iusticiam quam non facit homo, sed opus eius intelligi uoluit. [Ibid. 27.1.2 (ed. Brady, 480.14-16)]" Helinand, Chronicon 3.20; Vat. Bib. Apost., MS Reg. lat. 535, 36a-b. This manuscript is paginated, rather than foliated.

45. In addition to $c i u ., c$. Faust., and selected letters and sermons, we also find Helinand citing mend., conf., and Io. eu. tr.. He does not appear to have known trin., for he does not cite the work, even in sermo 16 , which is devoted to the Trinity.

46. Helinand also evidenced an awareness of pseudo-Augustinian writings. In sermo 3, Helinand cited from a prayer preceding the mass that was attributed to Ambrose. Helinand continued to note that in some manuscripts, the prayer is attributed to Augustine, but that, Helinand asserted, is incorrect, for Ambrose is named as author in the Pope's copy and the style, he argued, was completely in keeping with that of Ambrose. Helinand, sermo 3 (PL 212: 507D-508A): "Et beatus Ambrosius in oratione quae inter cantandum missam a sacerdote sedente dicitur: 'Panis pulcher, panis munde, panis uiue, panis sancte, panis candidissime, habens omne delectamentum, et omnem suauitatis saporem: qui nos reficis semper, et in te nunquam deficis: comedat te cor meum.' Haec enim oratio falso intitulatur in quibusdam missalibus sub nomine beati Augustini. Nam in exemplari domini papae intitulata est sub nomine beati Ambrosii, cuius et florentem stylum optime redolet." In addition, Helinand was aware of Augustine's own changing opinions on particular issues, such as the origin of the soul, affirming that Augustine had retracted his earlier position as reflected in his De quantitate animae. Helinand, Chronicon 8, London, BL Cotton Claudius B

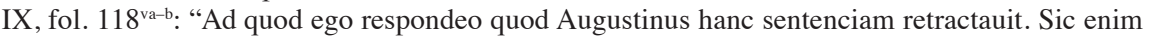
ait in retractatione eiusdem libri: Illud quod dixi omnes artes animam secum attulisse michi uideri nec aliud quicquam esse id quod dicitur discere quam reminisci et recordari non sic accipiendum est quasi ex hac approbertur animam uel hic in alio corpore uel alibi siue in corpore siue extra corpus aliquando uixisse et ea que interrogata respondet cum hoc non didicerit in alia uita ante didicisse fieri eim potest sicut iam in hoc opere supra diximus ut hec ideo possit quia natura intelligibilis est ut connectatur non solum intelligibilibus sed eciam immutabilibus rebus eo ordine facta ut cum se ad eas res mouet quibus connexa est uel ad se ipsam in quantum eas uidet in tantum de hiis uera respondeat nec sane omnes artes eo modo secum attulit ac secum habet nam de artibus que ad sesnsus corporis pertinent sicut multa medicine sicut astrologie omnia nisi quod hic didicit 
that of his erudition with respect to classical sources, ${ }^{47}$ while also surpassing that of his twelfth-century forbearers. Thus Helinand appears as the first thirteenth-century author to demonstrate the level of scholarly erudition that foreshadowed the source erudition that became the hallmark of the fourteenth-century Augustinian Renaissance. Yet, he did so without the personal appropriation of Augustine as the model for the religious life.$^{48}$ While Helinand did report in his Chronicon the second translation of Augustine from Sardinia to Pavia, drawn from Bede, ${ }^{49}$ and noted that the canonical life had been established by the apostles and then reestablished by Augustine,${ }^{50}$ there is no evidence that Helinand saw Augustine as anything more than as a doctor of the Church. Moreover, there is no indication that Helinand attempted to follow the teachings of Augustine. He used Augustine, but cannot be said to have imitated Augustine, or tried to compose his work in "thinking with" Augustine. ${ }^{51}$ Nevertheless, Helinand represents a transition in the medieval reception of Augustine from the Augustinian Renaissance of the twelfth century to that of the fourteenth century. As a result, Helinand has much to reveal regarding Augustine's reception with respect to his erudition with regard to the texts he cites, as well as with respect to the limits of his and his age's knowledge, use, and appropriation of Augustine.

non potest dicere ea uero que sola intelligencia capit, propter id quod dixi cum uel a se ipsa uel ab alio fuerit bene interrogata ac recordata respondet. hec Augustinus." Cf. retr. 1.7 (CSEL 36: 35.1-17).

47. E. R. Smits, "Helinand of Froidmont and the A-text of Seneca's Tragedies," Mnemosyne 36 (1983): 324-358.

48. Cf. Saak, Creating Augustine (n.35).

49. Helinand, Chronicon 45 (PL 212: 816B-C): "Luitprandus rex Longobardorum, audiens, quod Saraceni depopulata Sardinia loca illa foedassent, ubi ossa sancti Augustini doctoris magni, propter uastationem barbarorum olim translata fuerant, et honorifice condita, misit, et dato pretio accepit ea, et transtulit Ticinum; ibique cum debito Patri tanto honore condidit. Hucusque scripsit Beda Chronica sua, numerans ab initio mundi usque ad hunc Leonem, secundum Hebraicam Ueritatem, annos quatuor millia sexcentos octoginta."

50. Helinand, Chronicon 47 ad 1077 (PL 212: 964C-D): "Ab hoc tempore coepit reflorere in Ecclesia B. Quintini Beluacensis ordo canonicus, primum ab apostolis, postea a B. Augustino episcopo regulariter institutus, sub magistro Iuone uenerabili eiusdem ecclesiae praeposito, postea episcopo Carnotensi. Hoc tempore Petrus Damianus scripsit ad papam Hildebrandum, reddens rationem, cur episcopatum dimiserit."

51. It should, however, be kept in mind that the sections of the Chronicon covering the origins and rise of Christianity and the life of Augustine have been lost. It could very well have been that Helinand's treatment of such themes would have revealed a strong devotion to Augustine and would necessarily condition, alter, or render invalid my interpretation here. It is nevertheless clear from the text as we have it that Helinand did not compose his Chronicon using Augustine's two cities as a model. 


\section{Grosseteste}

In turning from the still relatively obscure figure of Helinand of Froidmont, to the well-known Robert Grosseteste, introductions can be dispensed with.$^{52}$ Suffice it to say that Grosseteste, as one of the major intellectual figures of the first half of the thirteenth century, had, in the words of James McEvoy, "read very widely in the works of Augustine and imbibed his spirit." ${ }^{53}$ As such, Grosseteste was more "Augustinian" than was Helinand. Yet we find the same, or at least a similar, use of Augustine evident in Grosseteste's Hexaemeron as we did with Helinand's Chronicon.

Grosseteste's Hexaemeron was composed shortly after Helinand completed his Chronicon, between 1232 and 1235. In it, Grosseteste displayed intimate knowledge of ciu.; we also know that he used MS Bodly 198 of the Bodleian Library.$^{54}$ Moreover, Grosseteste's Tabula, dated to ca. 1230, gives a very reliable key to which works of Augustine Grosseteste at least knew of at that time. ${ }^{55}$ In his Hexaemeron 1.8.2-3, in treating the eternity of the world, Grosseteste first cites ciu. 11.4, followed by 10.31 , but then turns to 12.10 and 13.16 , designated by Grosseteste simply as paulo post, and then finishes up with $12.13,{ }^{56}$ before continuing to present in brief the positions of Basel, Pliny, and Aristotle. Yet, at other times, Grosseteste simply refers to Augustine as one authority among others, such as in Hexaemeron 1.20.1, where Grosseteste exposits the "spirit of God" by referring first to Basel's Hexaemeron, and then notes: "and Augustine recounted this same meaning in book eight of $D e$

ciuitate dei. ${ }^{57}$ Despite being more lax with other works of Augustine, Grosseteste regularly gives book references for his citations of ciu. Thus, in Hexaemeron 1.23.1,

52. For the best introduction to Grosseteste, see James McEvoy, Robert Grosseteste, Great Medieval Thinkers (Oxford: Oxford University Press, 2000).

53. James McEvoy, "Robert Grosseteste" in OGHRA 2:1085-1086.

54. Robert Grosseteste: Hexaëmeron, ed. R. C. Dales and S. Gieben, OFM Cap. Auctores Britannici Medii Aevi 6 (London: Oxford University Press, 1982); hereafter abbreviated as Gross., Hex., with page and line numbers given in parentheses. For Grosseteste in general, see now McEvoy, "Robert Grosseteste" (n.53).

55. Tabula, ed. P. W. Rosemann, in Opera Roberti Grosseteste Lincolniensis, vol. 1, CCCM 130 (1995); P. W. Rosemann, "Robert Grosseteste's Tabula," in Robert Grosseteste: New Perspectives on His Thought and Scholarship, ed. J. McEvoy (Turnhout: Brepols, 1995), 321-55.

56. Gross., Hex. 1.8.2-3 (59.23-60.21) (n.54). According to the edition, Grosseteste cited trin. 12, though the editors note the passage is actually taken from ciu. 12,13; Gross., Hex. 1.8.3 (60.1921) (n.54). This, I would surmise, was a scribal error, reading trin. for ciu. Grossteste knew ciu. well and had already been citing it. If he indeed wrote De trinitate, I think it was a simple slip, and should not be taken as indicative of his knowledge of Augustine.

57. Gross., Hex. 1.20 .1 (79.21-34) (n.54): "Quod insinuat Basilius super hunc locum in Exameron, omelia secunda, et hanc eandem sentenciam recitat Augustinus in octauo libro De ciuitate dei." 
Grosseteste cites Augustine to exposit the "darkness" over the "abyss" simply by writing: "As Augustine said" (Ut enim ait Augustinus), followed by a quotation taken from Augustine's Tractatus in euangelium Iohannis (Io.eu.tr.) 18.5. ${ }^{58}$ This is then followed by a citation from Augustine's De Genesi contra Manichaeos (Gn. adu. Man.) 1.4.7, for which Grosseteste did give the book reference. ${ }^{59}$ Grosseteste also cited Augustine via the Glossa Ordinaria, as in Hexaemeron 8.28.1, without noting his intermediate source.$^{60}$ At times Grosseteste simply cited Augustine secundum Augustini sentenciam with no exact parallel in Augustine's works, offering an example of what Douglas Grey called the "diffused Augustinian tradition," ${ }^{61}$ even though Augustine is very much present. This phenomenon also points to the fact that, when determining the actual knowledge and use of Augustine in a given author, one cannot rely on the indices of critical editions for accurately representing what that knowledge and use actually were. The editors of Grosseteste's Hexaemeron, for example, list De spiritu et littera (spir.et litt.) and Questiones in Genesim (qu.uet.t.) as possible sources of Grosseteste's indirect reference to Augustine in Hexaemeron 8.6.1, and 11.5.4 respectively, despite the fact that, in the first passage, Grosseteste did not cite Augustine at all. ${ }^{62}$ Moreover, the reference to Augustine Grosseteste gave in Hexaemeron 11.5.4 is most likely taken from De Genesi ad litteram ( $G n$. litt.). ${ }^{63}$ The editors also note as other possible sources for the Hexaemeron, the Principia dialectice (dial.), qu. uet. t., and Sermo ad fratres in eremo 44. With regard to the passages where the editors cite the qu. uet.t. and the sermo as possible sources, Grosseteste did not cite Augustine; again the reference is given simply for parallels. ${ }^{64}$ The reference to dial. is a bit more complex. Grosseteste's text reads as follows: "Ipsa enim materia, ut dicit Augustinus, est mutabilitas rerum mutabilium, capax formarum omnium in quas mutantur res mutabiles." ${ }^{65}$ The editors first give the reference to $s .214 .2$, which reads: "Illa enim quae dicitur informis rerum ma-

58. Gross., Hex. 1.23 .1 (82.19-21) (n.54).

59. Gross., Hex. 1.23.1 (82.30ff) (n.54): "Augustinus quoque de hac eadem secta in libro I De Genesi contra Manicheos ait: ...."

60. Gross., Hex. 8.28.1 (252.10-15) (n.54).

61. Douglas Gray, "Saint Augustine and Medieval Literature I-II," in Saint Augustine and his Influence in the Middle Ages, ed. Edward King and Jacqueline T. Schaefer (Sewanee, TN: Sewanee Mediaeval Studies, 1988), 19-58.

62. Gross., Hex. 8.6.1 (227.27-28; spir. et litt. 28.48) (n.54).

63. Gross., Hex. 11.5 .4 (311.19-23) (n.54)

64. Gross., Hex. 8.10.2 (232.14-19; qu. uet.t.) (n.54); Gross., Hex. 8.3.1 (220,4-10; Sermo ad fratres in Eremo 44) (n.54).

65. Gross., Hex. 1.18 .3 (78.22-24) (n.54). 
teries, formarum capax et subiecta operi Creatoris." ${ }^{66}$ The passage the editors cited as an alternative, uel potius, from the dial. reads: "Informis materia est mutabilitas mutabilium rerum capax omnium formarum." ${ }^{67}$ Yet the text that is closer to that of Grosseteste is John Scotus Eriugena's De diuisione naturae 3: "Ita enim definitur materia est mutabilitas rerum mutabilium capax omnium formarum." ${ }^{.68}$ Eriugena had first discussed this formulation in book one, where he ascribed it to a conflation of Plato's Timaeus and conf.$^{69}$ Eriugena therefore leads us back to the source, namely conf. 12.6: "mutabilitas enim rerum mutabilium ipsa capax est formarum omnium in quas mutantur res mutabiles." ${ }^{70}$ Here, Grosseteste must not have been drawing directly from Augustine since none of the other possible sources included the last phrase "in quas mutantur res mutabiles," a detail that escaped the editors' attention. The point here is not to criticize the editors for having missed this reference, but to point to the difficulty in charting Augustine's reception even when using the best modern critical editions.

Given Grosseteste's extensive knowledge of Augustine, it may be rather a surprise to note that Augustine had a very limited role in Grosseteste's commentary on Aristotle's Physics. Composed for the most part between 1228 and 1232, Grosseteste's is the first known commentary on the Physics, the origins of which are most likely to be placed during his teaching the Arts at Oxford in the first decade of the thirteenth century, though they could stem from the time of his chancellorship at Oxford from 1214 to 1221, or during his time as principle lecturer to the Oxford Franciscans from ca. 1229 to his assuming the bishopric of Lincoln in $1235 .{ }^{71}$ Richard C. Dales, the editor of Grosseteste's Commentary on the Physics, claimed that Augustine was "certainly the most important source of Grosseteste's thought, not only in his Commentary on the Physics but also in his other works."72 For Grosseteste's Physics commentary, however, this assertion must be questioned.

66. S. 214.2 (PL 38: 1067).

67. Dial. 5 (PL 32: 1410).

68. Joannes Scotus, De diuisione naturae 3 (PL 122: 701C).

69. Eriugena, De diuisione naturae 1 (PL 122: 500C-D): "Multos de materia disputasse reperimus et mundanae, et diuinae sophiae peritorum; sed paucorum testimonio uti sat est. Sanctus Augustinus in libris Confessionum informem materiem esse asserit mutabilitatem rerum mutabilium, omnium formarum capacem. Cui assentit Plato in Timeo, similiter informem materiam esse dicens formarum capacitatem. His ambobus sibimet consentientibus potest sic dici et definiri: Mutabilitas rerum mutabilium capax omnium formarum informis materia est."

70. Conf. 12.6.6 (CCSL 27: ???).

71. Roberti Grosseteste Commentarius in VIII libros physicorum Aristotelis, ed. Richard C. Dales (Boulder: University of Colorado Press, 1963), vi (hereafter abbreviated as: Gross., Comm.).

72. Gross., Comm. (xviii) (n.71). 
Grosseteste mentioned Augustine only five times in the entire commentary, and did not cite any particular text of Augustine. Aristotle, on the other hand, is referenced throughout, just as one would expect. Yet, Grosseteste did not rely heavily on the works of previous scholars, a detail that permits one to argue that Augustine, the only patristic author cited, was indeed Grosseteste's "most important source," since he is the most frequently cited post-classical authority in Grosseteste's commentary. Grosseteste cited Averroes four times, Avicenna three times, the "Pythagoreans" three times, and Zeno and Richard of St. Victor twice, though Plato is mentioned seven times. Twice Grosseteste combined the authority of Plato and Augustine once regarding number, equating number and wisdom in the divine mind, ${ }^{73}$ and once regarding the infinity of wisdom and the eternal reasons of things (raciones rerum eterne) ${ }^{74} \mathrm{He}$ then referenced Augustine with regard to the Trinitarian structure of perfected reason ${ }^{75}$ and again with regard to time, relating time in Augustine to memory. ${ }^{76}$ The source of his discussion is conf. 11.26.32-34, which he then related to conf. 11.21.26, though without discussion of Augustine's concept of distentio animae, reducing Augustine's detailed analysis of time and time and memory to time being a measure of motion (mensura motus) and an affection left in the soul from the passing of things (affeccio relicta in anima ex transitu rerum mobilium). Grosseteste's own position is far closer to that of Aristotle than to that of Augustine ${ }^{77}$ and he certainly does not evidence a thorough knowledge of Augustine in this commentary. Moreover, Augustine is not present at all in Grosseteste's Commentary on the Posterior Analytics. ${ }^{78}$ Whereas Grosseteste used Augustine as his primary authority for his theological work, a close study of his appeals to Augustine's authority reveals that he did not have a major influence on Grosseteste's philosophical work.

The lack of Augustine in works of philosophy, at least to a certain extent, was a common feature of the high and later Middle Ages. This is particularly with respect to the Aristotelian tradition. ${ }^{79}$ Even before the complete incorporation of Aristotle into the university curriculum, Augustine's impact on natural philosophy was limited, a fact evidenced in the Salernitan Questions, the editor of which,

73. Gross., Comm. 3 (54) (n.71).

74. Gross., Comm. 3 (61) (n.71).

75. Gross., Comm. 3 (69) (n.71).

76. Gross., Comm. 4 (88, 95) (n.71).

77. Cf. Paul Ricoeur, Time and Narrative, v. 1, trans. Kathleen McLaughlin and David Pellauer (Chicago: University of Chicago Press, 1984), 5-51.

78. Robert Grosseteste, Commentarius in Posteriorum Analyticorum libros, ed. P. Rossi, Corpus Philosophorum Medii Aevi, Testi e Studi 2 (Florence: Olschki, 1981).

79. Maarten Hoenen, “The Aristotelian Tradition," in OGHRA 2:554-559. 
Brian Lawn, claims that, as a whole, the Salernitan Questions "are representative of the physica taught in the schools at the period ca. 1200." ${ }^{80}$ According to Lawn, Augustine is mentioned only once when reference is made to ciu. $21.4 .{ }^{81}$ Lawn notes Augustine as a possible source, together with others, in eleven additional loci, with nine references to $\mathrm{ciu}$. and two to trin. Aristotle is mentioned only twice,$^{82}$ though with seventeen citations as a possible source and an additional fifty-seven citations of pseudo-Aristotle.

The prevalence of Aristotle is more evident in John Blund's Tractatus de Anima, dating to the first decade of the thirteenth century during Blund's regency in Arts at Oxford.$^{83}$ Though Augustine is cited as an authority, Aristotle was Blund's primary guide. Blund cited Augustine nine times, only three of which give specific reference: once to ciu., lib.arb., and trin., though the reference to trin. is actually to conf. 10.11.18.$^{84}$ Three of the remaining six references to Augustine combine the authority of Augustine and Aristotle, demonstrating their agreement ${ }^{85}$; another reference combines the authority of Augustine and Jerome, together with aliis auctoribus to prove that the soul, existing in the body, is oppressed by the flesh, ${ }^{86}$ which is then followed by a quotation from Aristotle's Posterior Analytics; Blund then draws on the authority of Boethius and Augustine, and others, that free will is stronger (magis uiget) in angels than in humans ${ }^{87}$; and the final citation to Augustine is his presentation of Plato's opinion of the world soul, which Blund claims Augustine neither affirmed nor denied, a position that is evident, as the editors point out, in Augustine's De consensu euangelistarum (cons. eu.) 1.23.35; in Blund's opinion, the world soul is nothing other than the vivifying and ruling of the Holy Spirit. ${ }^{88}$ The editors have noted an additional thirty instances where Augustine was a likely source, though he remained uncited ${ }^{89}$ Blund's use of Augustine contrasts markedly with

80. The Prose Salernitan Questions. Edited from a Bodleian Manuscript (Auct. F. 3. 10), ed. Brian Lawn, Auctores Britannici Medii Aevi V (Oxford: British Academy, 1979), xix (hereafter abbreviated as Lawn, Sal. Quest.).

81. Lawn, Sal. Quest. W 1 (263.7) (n.80).

82. Lawn, Sal. Quest. B 301; R 20 (143.9, 346. 4) (n.80).

83. Johannes Blund, Tractatus de Anima, ed. D. A. Callus and R. Hunt (London: Oxford University Press, 1970), viii (hereafter abbreviated as Joh. B1., anima).

84. Joh. B1., anima, 25.2 .346 (94.25-6) (n.83).

85. E.g., Joh. B1., anima 3.34 (9.24-5) (n.83): “. . tam Aristoteles quam Augustinus ...”

86. Joh. B1., anima, 25.3.367 (101.15-7) (n.83).

87. Joh. B1., anima, 26.2.402 (111.25ff) (n.83).

88. Joh. B1., anima 25.2.360 (98.18-23) (n.83).

89. Joh. B1., anima 2.1.16 (5.3-6.3) (n.83). These include, in addition to ciu., lib. arb., trin., conf., and cons.eu., c.ep.Man., ep.Io.tr., Gn.litt., an.et or. and Io.eu.tr., and there is one further indication 
that of Aristotle, whom Blund cited explicitly forty-two times, with an additional 125 instances as an uncited source. Aristotle, not Augustine, was Blund's principle authority for his treatment of the soul, though Blund seems to have endeavored to bring in Augustine's authority, blending it with his basically Aristotelian approach.

A more thorough and detailed knowledge of Augustine than is evident in Grosseteste's Physics commentary or Blund's commentary on De Anima is seen in Thomas Aquinas's Quaestiones de Anima. These were a series of disputed questions held most likely in Paris in the second half of the academic year 1268-1269, during Thomas's second sojourn in Paris. ${ }^{90}$ Here Thomas cited Augustine thirty-three times, the most frequently cited authority after Aristotle with 144 citations. Plato is in third place regarding frequency of citation with sixteen, followed by PseudoDionysius with twelve and Averroes and Avicenna each with six. Moreover, Thomas cited from eleven works of Augustine, ${ }^{91}$ with reference to $\mathrm{Gn}$. litt. the most frequent with eight citations, followed by trin. with seven, and ciu. with six. He routinely gave book references for ciu., Gn. litt., and trin., and only six times did Thomas reference Augustine without giving a title. Moreover, Thomas exhibited a detailed knowledge of Augustine, as seen in question nineteen, whether a sensitive power remains in separated souls, when Thomas responded to the sixth argument pro based on Gn. litt. $12^{92}$ by arguing that Augustine had retracted this position in his retr., and Thomas then quoted the passage. ${ }^{93}$ Likewise in question twenty-one, dealing with the issue of whether separated souls can suffer punishment from corporeal fire, the nineteenth argument pro cited Gn. litt. 12 to affirm that the substance of souls in hell are not believed to be corporeal, but spiritual, ${ }^{94}$ to which Thomas replied that Augustine stated such in the sense of inquiry, not in that of determining a question, and in any case he had revoked such an opinion in ciu. $21 .{ }^{95}$ Further, Thomas referenced the pseudo-Augustinian De spiritu et anima three times, each of which he warned his reader that it was not a work of Augustine, ${ }^{96}$ and in question twelve, suggested it was authored by "some Cistercian," ${ }^{97}$ which we know it was, Alcherius

that the ps.-Augustine De spiritu et anima was a possible source.

90. Thomas Aquinas, Quaestiones de Anima, ed. James H. Robb, Studies and Texts 14 (Toronto: Pontifical Institute of Medieval Studies, 1968), 27-36 (hereafter abbreviated as. Thom.Aq., anima).

91. Conf., ciu., cura mort., diuin. daem., Gn. litt., imm. an., nat. b., an .quant., trin., ench., and the retr.

92. Thom.Aq., anima 19 (246; Gn. ad lit. 12.32) (n.90).

93. Thom.Aq., anima 19 (250-251; retr. 2.24) (n.90).

94. Thom.Aq., anima 21 (267; Gn. ad lit. 12.32) (n.90).

95. Thom.Aq., anima 21 (271; ciu. 21.10) (n.90).

96. Thom.Aq., anima 9 (142.149) (n.90); ibid., 12 (177.182); ibid., 19 (245.250).

97. Thom.Aq., anima 12 (182) (n.90): “. . . liber iste De spiritu et anima non est Augustini, sed dicitur cuiusdam Cisterciensis fuisse ..." 
Claravellensis. Even in a philosophical work such as his Quaestiones de Anima, the "Aristotelian" Thomas demonstrated his erudition with respect to Augustine's works, which served as Thomas's primary authority after Aristotle. ${ }^{98}$

The inferred dichotomy between "Aristotelianism" and "Augustinianism" has shaped portrayals of thirteenth-century philosophy for over a century. Scholars from De Wulf and Gilson to Steven Marrone have, with considerable variation in terms of characterizing and demarcating the possible subdivisions of these two general categories, including the influence of Jewish and Muslim thought, which, at times, results in an additional third "school" of Latin Averroism, all regard scholastic philosophy to be generally divisible into these two, or three, philosophical schools, with the Aristotelians represented most stereotypically by Albert the Great and with the Augustinians represented by Aquinas, Bonaventure, John Pecham, and Henry of Ghent. ${ }^{99}$ Yet the historical validity of such bifurcation, when one analyzes in detail the arguments of the scholastics, should be called into question based on the recognition that the labels are rarified terms employed by philosophers, theologians, and historians to describe historical phenomena that may or may not have had anything to do at all with the historical, or received, Aristotle or Augustine.

Other scholars have resisted the seduction of such categorization. Dales, in his study of the rational soul in the thirteenth century, asserted that he was not "concerned with classifying writers ... or in determining whether they were Avicennists, Augustinians, or Aristotelians - indeed, they were all indebted to some degree to all three of these auctoritates, ${ }^{\prime 100}$ and in his study of the question regarding the eternity of the world, Dales concluded that he did

not see that there is anything to be gained by referring to our authors as Augustinians or Aristotelians in this matter. All authors cited and used both authorities extensively, and I have found no one who accepted intact the thought of either, a circumstance which was intensified by the custom of citing snippets of authorities and often ignoring context. ${ }^{101}$

98. Cf. Michael Dauphinas, Barry David, and Matthew Levering, eds., Aquinas the Augustinian (Washington, D.C.: Catholic University of America Press, 2007).

99. John Francis Quinn, The Historical Constitution of St. Bonaventure's Philosophy (Toronto: Pontifical Institute of Medieval Studies, 1973), 17-99; cf.: Steven P. Marrone, The Light of Thy Countenance: Science and the Knowledge of God in the Thirteenth Century, 2 vols. (Leiden: Brill Academic Publishers, 2001).

100. Richare C. Dales, The Problem of the Rational Soul in the Thirteenth Century, Brill's Studies in Intellecutal History 65 (Leiden: Brill Academic Publishers, 1995), 1.

101. Richard C. Dales, Medieval Discussions of the Eternity of the World, Brill's Studies in Intellectual History 18 (Leiden: Brill Academic Publishers, 1990), 259. 
Dales's insights are supported by the examples given above, with the "Aristotelian" Thomas as the most "Augustinian." Despite the apparent lack of Augustine's influence in the Aristotelian tradition, Augustine served as a foundational text for major philosophical questions. As Dales noted concerning the eternity of the world:

The three principle authors to whom medieval Latin philosophers were indebted for their knowledge of ancient thought on the eternity of the world were Plato, Augustine, and Boethius. Although others were recovered during the twelfth and thirteenth centuries, these three were known uninterruptedly, and until the second quarter of the thirteen century they provided the context, the point of departure, and many of the stock arguments on both sides of the question. Even after the recovery of Aristotle's natural philosophy and the translation of medieval Jewish and Muslim works into Latin, these three authors maintained their preeminent position among the authorities. ${ }^{102}$

Augustine was likewise the foundational authority for philosophers holding to the unicity of the soul regarding the question of the rational soul, and for epistemologies relying on divine illumination. ${ }^{103}$ In short, Augustine was a standard authority for various philosophical issues debated in the thirteenth through fifteenth centuries, despite the relative absence of Augustine from commentaries on Aristotle's works as such. In this light, one could say that with respect to high and late medieval philosophical literature, Augustine was cited as an authority without an attempt to philosophize in keeping with Augustine's thought. In other words, Augustine's authority and texts were foundational for philosophy, but in general no scholastic pursued natural philosophy based on a distinctive appropriation of Augustine.

There could however, be exceptions to this general rule. Henry of Ghent, for example, according to Raymond Macken, strove

to give a satisfactory scientific foundation to the thought of his beloved Augustine. At the same time he represents a later evolution and a personal appropriation of Augustine's thought, influenced as well by some ideas of Aristotle, Avicenna, and other medieval scholastics. Indeed Henry's development of the Augustinian tradition assumes a personal and daring form. ${ }^{104}$

102. Ibid., 3 .

103. Lydia Schumacher, Divine Illumination. The History and Future of Augustine's Theory of Knowledge (Oxford: Wiley-Blackwell, 2011).

104. Raymond Macken, O.F.M., "Henry of Ghent and Augustine," in Ad Litteram. Authoritative Texts and Their Medieval Readers, ed. Mark D. Jordan and Kenty Emery Jr. (Notre Dame: University of Notre Dame Press, 1992), 251-274; 270. 
though Pasquale Porro has argued that the critical edition of Henry's works, still in progress, has necessitated a re-evaluation of Henry's traditional "Augustinianism," recognizing that Henry "sought to reconcile traditional Augustinian theories with some of the basic principles of Aristotelian epistemology and Avicennian ontology, thereby giving rise to a complex and original synthesis." 105 The relative lack of true appropriation of Augustine by the majority of scholastics could have been the result of the fact that Augustine did not have a place in the university curriculum, even though he did exert an influence in elementary education. ${ }^{106}$

Grosseteste, therefore, fits within the general pattern of Augustine's reception with respect to medieval philosophical literature: there is no basis to claim that in this context Grosseteste had any special knowledge of Augustine at all. Augustine was, however, Grosseteste's primary authority in his theological works, as is evident not only in his Hexaemeron as seen above, but likewise in his De decem mandatis and Expositio in Epistolam Sancti Pauli ad Galatas. In his De decem mandatis, Grosseteste cited Augustine sixty-seven times, the overwhelming leader among Grosseteste's non-Scriptural authorities. Jerome is the next most frequently cited authority with sixteen citations. Of these sixty-seven, forty-seven give specific reference to the work and often book, though Grosseteste never gives references to chapters within books. Thirty, namely almost half, of the sixty-seven citations are found in Grosseteste's treatment of commandments eight through ten. De nuptiis et concupiscentia ad Valerium (nupt.et conc.) is the most frequently cited work of Augustine, Grosseteste having cited it ten times, followed by $c$. Iul. and ciu. each with seven citations, and five citations of various letters of Augustine. ${ }^{107}$ Grosseteste cited from twenty-two separate works of Augustine, only six of which he

105. Porro Pasquale, "Henry of Ghent," in Stanford Encyclopedia of Philosophy (Fall 2014 Edition), ed. Edward N. Zalta, http://plato.stanford .edu/entries/henry-ghent/.

106. See Mitchell Harris, "Education," in OGHRA 2:922-928.

107. In Grossteste's De Decem Mandatis 6,19 (ed. R. C. Dales and E. B. King, Auctores Britannici Medii Aevi 10 (London: Oxford University Press, 1987); hereafter abbreviated as Gross., De dec.man., the editors give a reference to $c$. Iul. for Grosseteste's citation prefaced by: “. . . ex uerbis Augustini in eodem libro dicentis ..."; Gross., De dec. man. 6.19 (73.32). They also include quotations marks at the beginning of the quotation, with no ending quotation marks. They give no book reference within $c$. Iul., though the previous citation to the work they do give the reference as $c$.Iul. 5.16.59, which indeed is the preceeding citation to the one in question here. Grosseteste was being a bit unclear. The quotation is found in nupt. et conc. 1.14.16 (PL 44: 423). This may have been a simple slip of the mind on Grosseteste's part, since the work he cited previous to his quotation from $c$. Iul. 5.16.59 is nupt. et conc. 1.4.5, to which his in eodem libro refers; he may have added the quotation from c. Iul.5.16.59 later, without having then corrected his citation. 
did not name by title. ${ }^{108}$ Three citations are unknown, meaning neither the editors nor myself could find the reference; ${ }^{109}$ twice where Grosseteste cited Augustine without naming a work the editors have noted parallel passages as possible sources, once to trin. ${ }^{110}$ and once to $c$. Iul. $;{ }^{111}$ and as mentioned above, the editors offered four possibilities as the source(s) behind Grosseteste's citing Augustine secundum sentenciam Augustini. ${ }^{112}$ The Hypomnesticon is the only Pseudo-Augustinian work Grosseteste cited in De decem mandatis, which he did twice. ${ }^{113}$

In short, Grosseteste demonstrated an impressive knowledge of Augustine's works in both breadth and depth. Moreover, he evidenced a facility with Augustine's texts that surpassed the mere citing of standard quotations. In De decem mandatis 9 , for example, Grosseteste constructed his text by incorporating numerous quotations from Augustine. Thus, after introducing the theme of the ninth commandment, namely the one about not coveting your neighbor's wife, or house etc., Grosseteste began by quoting Galatians 5:17, even though he labeled it as Ephesians. ${ }^{114}$ Then he quoted a phrase from $c$. Iul. 4.14.65. ${ }^{115}$ Six lines (in the critical edition) later,

108. Perf. ius., ep. 153, ep. 190, ep. 243, ench. and s. 350.

109. Gross., De dec. man. 1.1 (6.9-12); 8.7 (82.21-23); 9-10.9 (88.33-89.9) (n.107). No reference was given by the editors for this last citation, nor did they note it as non inuenitur. I have not been able to find a direct reference, but the passage does parallel Augustine c. ep. Pel. 3.23 (PL 44: 605-606).

110. Gross., De dec. man. 4.19 (46.9-11) (n.107).

111. Gross., De dec. man. 8.6 (82.19-20) (n.107).

112. Gross., De dec. man. 2.8 (26.11-22) (n.107). The editors note parallels to nat. b. 7; ep.120.2; ench.11; and agon. 7. Grosseteste could well have had all these passages in mind. In his Glossarum in sancti Pauli Epistolas Fragmenta, treating 1 Thess. 4:2, Grosseteste noted: “. . . sicut haberi potest ex uerbis beati Augustini in libro De uera religione et libro De Trinitate et libro X et $13^{\circ}$ Confessionum." For this see Ad 1 Thess. (ed. Dales, 225.60-62; hereafter abbreviated as: Gross. Gloss.).

113. Gross., De dec. man. 9.2 (85.28-86.2) (n.107). The two citations are to Hypomnesticon 4.1.1 and then immediately another quotation from Hypomnesticon 4.4.4.

114. Gross., De dec. man. 9.2 (85.10-12) (n.107).

115. In Gross., Hex. 9.2 (85.13-21) (n.54), the editors give the reference simply to c. Iul.4.65, leaving out the chapter reference. Moreover, they designate the passaged quoted with quotation marks as follows: "ut testatur Augustinus, "siue consentientes mente siue repugnantes impellit ad dilectacionem uoluptatis in senciendo uel sciendo uel dominando, et hec concupiscencia dicitur lex membrorum et lex peccati et tyrannus carnis et peccati fomes. Hec in nondum renais est culpa. In renatis autem et caritate informatis est origianlis peccati sola pena. Hec non est in nostra potestate quin insurgat, uelimus nolimus, etiam contra racionis imperium. Hec non est in natura hominis a Deo conditore creata, sed de primo primi hominis peccato nata." The problem here is that only the first line is from c. Iul. 4.14.65 (PL 44: 770), which reads as follows: "Necessitas sentiendi est, quando sensibus nostris etiam quae nolumus ingeruntur. Libido autem sentiendi est, de qua nunc agimus, quae nos ad sentiendum, siue consentientes mente, siue repugnantes, 
Grosseteste cited one sentence from nupt. et conc. 1.1.1, followed immediately with another from nupt. et conc. 1.5.6 and a quotation of four lines (in the critical edition) from nupt. et conc. $1.12 .13 .{ }^{116} \mathrm{He}$ then gave parallel passages from the Hypomnesticon 4.1.1 and 4.4.4. ${ }^{117}$ Grosseteste then returned to nupt. et conc., quoting five lines of text (in the critical edition). ${ }^{118}$ Ten lines later, he quotes four lines from $c$. Iul. 2.3.7, adds four lines of his own comments, and then presents a string of quotations from $c$. Iul. 3.16.30; 4.2.9; and 5.7.38, amounting to thirteen lines in the edition. ${ }^{119}$ This series of quotations could not have been taken from an intermediate source, a fact which demonstrates Grosseteste's direct knowledge of Augustine's works. It is also significant that all three of the texts Grosseteste cited here are also listed in his Tabula. ${ }^{120}$

In his Expositio in Epistolam Sancti Pauli ad Galatas, Grosseteste followed Augustine as his primary theological guide, even though he used other patristic sources exegetically. Grosseteste cited Augustine thirty-six times; ${ }^{121}$ but he also

appetitu carnalis uoluptatis impellit. Haec est contraria dilectioni sapientiae, haec uirtutibus inimica. Hoc malo, quantum attinet ad eius eam partem qua sibi sexus uterque miscetur, bene utuntur nuptiae, cum coniuges procreant filios per illam, nihilque faciunt propter illam. Hanc si uoluisses uel ualuisses a sentiendi uiuacitate, utilitate, necessitate discernere, uideres quam superfluo tam multa dixisses. Non enim ait Dominus, Qui uiderit mulierem, sed, qui uiderit ad concupiscendum, iam moechatus est eam in corde suo [Matth. V, 28]. Ecce sensum uidendi a libidine sentiendi, si peruicax non sis, breuiter aperteque discreuit. Illud Deus condidit, instruendo corpus humanum: illud diabolus seminauit, persuadendo peccatum." The term peccati fomes does not appear in the works of Augustine. There is a close parallel between Grosseteste's et hec concupiscencia dicitur lex membrorum et lex peccati et tyrannus carnis et peccati fomes, but it is not Augustine; rather, in Innocent III, De contemptu mundi 1.4 (PL 217: 704B), we read: "In carnali quippe commercio, rationis sopitur intuitus, ut ignorantia seminetur: libidinis irritatur pruritus, ut iracundia propagetur: uoluptatis satiatur affectus, ut concupiscentia contrahatur. Hic est tyrannus carnis, lex membrorum, fomes peccati, languor naturae, pabulum mortis, sine quo nemo nascitur, sine quo nullus moritur: qui si quando transit reatu, semper tamen remanet actu." The main point is that modern critical editions cannot be automatically relied either to trace or to analyze the reception of an earlier author. The apparatus fontium only points one to intertextual references, sometimes accurately, sometimes not. To determine precisely how Grosseteste used Augustine, one would have to analyze not only every citation, but also every reference given in the critical editions; indeed, one would need to return to the actual manuscripts Grosseteste had before his eyes.

116. Gross., Hex. 9.2 (85.21-28) (n.54).

117. Gross., Hex. 9.2 (85.28-86.2) (n.54).

118. Gross., Hex. 9.3 (86.8-13) (n.54).

119. Gross., Hex. 9.4 (86.20-87.8) (n.54).

120. Rosemann, "Robert Grosseteste's Tabula," 340-342 (n.55).

121. J. McEvoy, ed., introduction to Expositio in Epistolam Sancti Pauli ad Galatas by Robert Grosseteste, CCCM 130 (1995), 9, hereafter abbreviated as Gross., Exp. ad Gal. 
cited Jerome 125 times. Of his thirty-six citations of Augustine, Grosseteste cited Expositio ad Galatas only three times and never by name or via a specific reference. ${ }^{122}$ Grosseteste cited Jerome's Commentarius in Epistolam ad Galatas 119 times. In his Expositio, Grosseteste also cited the Greek Fathers John Chrysostom and Theophylactus. He cited Chrysostom's In Epistolam ad Galatas commentarius twenty-eight times, but by name only eight times; Theophylactus's Commentarius in Epistolam ad Galatas is cited sixty-four times but never by name; he always refers to it only as expositor graecus. ${ }^{123}$ As McEvoy has noted: "Grosseteste was the first scholar to attempt to read and exploit all the commentaries available, for the light they might throw on the interpretation of the epistle." ${ }^{124}$ In light of this, how could I claim that Augustine was Grosseteste's primary theological guide? As McEvoy further clarified, pointing to the parallels between Grosseteste's Expositio and his De decem mandatis:

Now the Augustinian theme of charity in practice as being the sole valid interpreter of the senses of Scripture ... runs like a dominant theme through both works of Grosseteste, accompanied by the doctrine of amor ordinatus and the reduction of the commandments to one, which is inseparably the love of God and of the neighbor - the Johannine theme so beloved of Augustine. ${ }^{125}$

Thus Grosseteste appealed to Augustine against Jerome regarding the question of justification through the law. In his Commentarius in Epistolam ad Galatas, Jerome had explained that "it is possible, therefore, that there is someone who is just and nevertheless is without faith in Christ." ${ }^{126}$ Grosseteste denied that Jerome's true meaning was that one could become iustus sine fide, and he did so with Augustine as proof. ${ }^{127}$ It is not just the number of citations of Augustine relative to other authorities that must be analyzed in order to discern Augustine's reception history;

122. Gross., Exp. ad Gal. 3.15 (85.498-499) (n.121); 3.21 (89.646-647); 5.39 (158.1025-1026).

123. McEvoy, intro to Exp. ad Gal., 12-14 (n.121).

124. Ibid., 8 .

125. Ibid., 16.

126. Hieronymus, Commentarius in Epistolam ad Galatas 2 (PL 26: 384): "Potest ergo fieri, ut sit aliquis iustus et tamen sine fide Christi." as cited by Gross., Exp. ad Gal. 3.15 (84.473-85.476).

127. Gross., Exp. ad Gal. 3.15 (85.477-502): "Sed numquid haec sententia Hieronymi uera est, scilicet aliquem posse esse iustum absque fide Christi, adhuc secundum quod iustitia proprie et uere dicta est uirtus animi, rectitudo uidelicet uoluntatis seruata propter se? Sed uoluntas nullo modo recta est quae a suo factore et redempore Christo, qui est uera rectitudo et uera iustitia, distorta est; qua propter non potest esse haec iustitia sine fide diligente; quod etiam Augustinus ostendit euidenter in pluribus locis, uidelicet quod infidelibus non potest esse uirtus aliqua cum infidelitate ... Immo uero, ut ostendit Augustinus, fides ex gratia datur, et non ex meritis misericordiam consecutus sum, ut essem fidelis. Quicquid igitur uoluerit per sermonem suum intelligere Hiero- 
rather, one must also assess the significance of such citations and how they are used. While Grosseteste used Jerome for his guide to the text of Galatians, Augustine remained the dominant interpretive source for his commentary. This holds true for his other exegetical works as well, including his Glossarum in sancti Pauli Epistolas Fragmenta ${ }^{128}$ and commentary on Psalm 100 of his Super Psalterium, his lengthiest biblical commentary. ${ }^{129}$

What then can we say about Grosseteste's reception of Augustine in general? First of all, Grosseteste demonstrated an extensive knowledge of Augustine's works that places him among the very best Augustine scholars of the high Middle Ages. Moreover, his command of his sources, most of which he knew firsthand, is impressive. He seems to have acquired this knowledge through his own reading of Augustine, a practice he developed from the time of his inception as Master of Theology in $1229 / 30 .{ }^{130}$ In his Hexaemeron, dated to the years 1232-1235, Grosseteste showed an extensive knowledge of Augustine, more so than in his De decem mandatis of ca. $1230 .{ }^{131}$ Certainly Grosseteste did not begin reading Augustine in 1229/30, as his Tabula witnesses, but there is no evidence that he had acquired an extensive knowledge of Augustine's texts before this date, given the contents of his Physics Commentary and that on the Posterior Analytics. We must be careful not to read the clear influence of Augustine as evident in his later theological work back into his earlier philosophical works. Yet, we can say that by 1230 , shortly after Helinand had completed his Chronicon, Grosseteste had acquired an erudite and extensive knowledge of Augustine, by reading Augustine's own works firsthand.

\section{Conclusion}

The foregoing allows us to draw four primary conclusions regarding the reception of Augustine as such in the thirteenth century. First is that, in order to discern Augustine's reception, we cannot rely on critical editions, which so often seek to

nymus, firmiter credendum quod fides confertur gratis et non ex credentis praecedentibus bonis meritis."

128. Gross. Gloss. (ed. Dales, 177-231) (n.112). This work consists of glosses and short commentaries on Romans, 1 and 2 Corinthians, Ephesians, Philippians (consisting only of one gloss on Phil. 1:12), Colossians, 1 Thessalonians, Timothy, Titus, and Hebrews.

129. James Ginther, Master of the Sacred Page. A Study of the Theology of Robert Grosseteste, c. 1229/30-1235 (Aldershot: Ashgate, 2004), 155. Grosseteste's Super Psalterium has not been edited. Ginther provides a transcription of Grosseteste's exposition of Ps. 100 from Bologna, Biblioteca dell'Archiginnasio MS 983, fol. $168^{\mathrm{vb}}-173^{\mathrm{vb}}$ in the appendix to his monograph; Ginther, Master of the Sacred Page, 193-211.

130. Rosemann, "Robert Grosseteste's Tabula," 329-330 (n.55).

131. Gross., Hex., Intro. (vii) (n.54). 
demonstrate the erudition of the editors rather than that of the authors being edited. Medieval authors chose when to cite Augustine and when not to, a fact that renders seeking Augustine's reception by means of explicit citation precarious.

Second, pseudo-Augustinian texts were received as authentic. For Grosseteste, as well as for Thomas and Lombard, the De fide ad Petrum was an authentic text of Augustine, even as Thomas recognized at times spurious attributions. What for us today is Pseudo-Augustinian, was for the thirteenth century genuine and authentic, and this must play a role in our understandings of Augustine's reception without allowing the hubris of our modern knowledge to affect our understandings of that reception in the thirteenth century: the thirteenth-century reception of pseudo-Augustinian texts is central to our understanding of the thirteenth-century reception of Augustine as such.

Third, it was only in the early fourteenth century that Augustine once again assumed the designation pater noster, a viewpoint that combines the academic scholarly erudition of Augustine's texts with a religio-cultural appropriation of Augustine as the model for the religious life. This, in turn, signals a qualitative and quantitative shift in the knowledge, use, and appropriation of Augustine. What we find in the thirteenth century is, to adapt the insight of Damasus Trapp, an Augustine without an Augustinianism. ${ }^{132}$ Before the fundamental shift in Augustine's reception in the late medieval Augustinian Renaissance, Helinand, running ahead of the great scholastics, represented the apogee of Augustine's reception, as a product of the twelfth-century Augustinian Renaissance, and, as such, has far more to reveal to us about the "pre-scholastic" intellectual world than one might think a "mere" encyclopedist would. If we view Helinand as "only" an encyclopedist, or as "only" a "compiler," we will fail to understand Helinand, his work, and his world. The encyclopedists must be included in our investigations, interpretations, and portrayals of the intellectual history of the thirteenth century.

And finally, if we desire to understand the reception of Augustine in the Middle Ages, the thirteenth century is a pivotal period of transition, and was so even before the flowering of scholasticism in Paris. Yet if we desire to understand the reception of Augustine in the early thirteenth century, which provides the basis for any attempt to discern his influence or impact, we have our work cut out for us. We

132. Damasus Trapp, "Harvest of Medieval Theology [Notes on Heiko A. Oberman's book, The Harvest of Medieval Theology]" Augustinianum 5 (1965): 147-151; 150: "What happened in the Early, in the High, and in the Late Middle Ages may, who knows, be pressed into the following somewhat daring formula: early scholasticism had both an Augustine and an Augustinianism of its own; Aristotelic Thomism had an Augustine but no Augustinianism; late scholasticism rediscovered Augustine within an Augustinianism of its own!" 
must ourselves return to the manuscripts and their marginalia, and we must do so with the recognition that citing Augustine in and of itself doesn't mean all that much. How was Augustine being cited? How was Augustine being used? How was Augustine known? What does Helinand's and Grosseteste's "cutting and pasting" of Augustine really mean aside from being an interesting observation? Somehow, Lombard's systematic compilation of Augustinian sententiae in his Sentences is more straightforward than that. In Lombard's wake, what are we to make of it all? Only with much further work, and much further pondering, will we come to a point at which we can begin to describe historically Augustine's reception in the early thirteenth century, something that is obviously necessary for any accurate and genuine understanding of the textual and intellectual history of the high and later Middle Ages. 


\section{Appendix}

Helinandi de Frigidi Montis Chronicon, 2,60-71

London, British Library, Cotton MS Claudius B IX, fols. 19²-20 ${ }^{\text {va }}$.

This appendix illustrates Helinand's compilation process with respect to Augustine. It follows the text of Helinand's Chronicon 2.60-71 from the London manuscript, which represents an earlier version of the text than does the Vatican manuscript. I have used italics for text Helinand drew from ciu., giving the references in the

footnotes. Helinand's summaries of Augustine's text are not printed in italics, but the references are given in the footnotes. The capitulation, namely, chapters 60-71, follows that of the Vatican manuscript. The London manuscript does not number the chapters, nor does it give a listing of chapters. The reader will notice that the text division in the London manuscript is slightly different from that in the Vatican. Thus the text begins without a paragraph sign, which in the Vatican manuscript is a rubricated chapter title and number, namely, chapter 60; in the London manuscript, this text is approximately half way between paragraph signs. The marginalia in the London manuscript is likewise far less frequent than in the Vatican manuscript. I have noted in the text below the marginal notations in the London manuscript in brackets after the paragraph sign in the text where the marginals appear. I have followed the orthography of the London manuscript. The Helinand Project at the University of Groningen, led by C. H. Kneepkens, has been working on the critical edition of Helinand's Chronicon for a number of years. It is hoped that their edition, based on the Vatican manuscript, will appear in the near future. My work on Helinand began as a member of this group during the years 1995-1999. 
//fol. 19rb// Idem. Plotinus sepe multumque asserit sensum Platonis explanans ne illam quidem quam dicunt esse uniuersitatis animam aliunde beatam esse quam nostram idque esse lumen quod ipsa non est, sed a quo creata est, et quo intelligibiliter illuminante intelligibiliter lucet et dat similitudinem ${ }^{133}$ a sole et luna tanquam illud sit sol et ipsa luna. Dicit ergo animam rationalem siue potius intellectualis dicenda sit ex quo genere etiam immortalium beatorumque animas esse intelligit quos in celestibus sedibus habitare non dubitat, non habere supra se naturam nisi dei, nec aliunde illis supernis spiritibus preberi uitam beatam, quam unde et nobis, ${ }^{134}$ idest ex uisione dei quam tante pulchritudinis et tanto amore dignissimam esse dicit, ut sine hac quibuslibet aliis bonis preditum atque habundantem non dubitet infelicissimum dicere.

I $<$ in marg.: Quomodo Porphirius distinguit inter angelos $>$ Porfirius autem dicit alios angelos qui deorsum descendentes hominibus theurgicis diuina prenuntient, alios autem qui in terris ea que patris sunt et altitudinem eius profunditatemque declarent. ${ }^{135}$ Optime autem admonet eos imitandos potius quam inuocandos. Non $n^{136}$ autem reuera demones cadaueribus nidoribus, ut ait Porfirius, sed //fol. 19va// diuinis honoribus gaudent. ${ }^{137}$

I $<$ in marg.: Apuleius de familiaribus demonibus $>$ Ex hoc autem pessimo genere demonum dicit Apuleius illam esse Mineruam, que, ut Homerus fi mediis cetibus Graium cohibendo Achilli interuenit et ex alia parte Troianorum scilicet alius demon dictus Mars uel Venus. Iuno autem que Grece dicitur Hera et ideo nescio quis filius eius secundum Grecorum fabulas heros appellatus est. Hoc ueluti misticum uidetur significare quod aer Iunoni deputetur, ubi uolunt heroas cum demonibus habitare quo scilicet nomine appellant animas defunctorum alicuius meriti. ${ }^{138}$

$\mathbb{I}<$ non rubricata $>\mathrm{Hec}$ autem Iuno non usquequaque inconuenienter a poetis inducitur inimica uirtutibus et celum petentibus ${ }^{139}$ inuida. Sed rursus ei succumbit infeliciter ceditque Virgilius, ut cum apud eum illa dicat:

Vincor ab Enea

ipsum Eneam admoneat Helenus uates quasi consilio religioso et dicat:

133. Сіи. 10.2 (CCSL 47: 274.7-11).

134. Сіи. 10.2 (CCSL 47: 274.13-21).

135. Сіи. 10.26 (CCSL 47: 300.4-7).

136. Сiu. 10.26 (CCSL 47: 300.9-11).

137. Cf. ciu. 10.26 (CCSL 47: 300.11-301.39).

138. Сf. сіи. 9.7 (CCSL 47: 255.1-256.39).

139. Сіи. 10.21 (CCSL 47: 295.22-23). 
Iunoni cane uota bibens dominamque potentem

supplicibus supera donis. ${ }^{140}$

IEx qua opinione Porfirius quamuis non ex sua sententia, sed ex aliorum dicit bonum deum uel genium non uenire in hominem nisi malus fuerit et ante placatus; tanquam fortiora sint apud eos numina mala quam bona, quandoquidem mala impediunt adiutoria bonorum nisi eis placata dent locum, malisque nolentibus prodesse bona non possunt, nocere autem mala possunt non sibi ualentibus resistere bonis. ${ }^{141}$

IVera autem pietate homines dei aeriam potestatem inimicamque pietati exorcizando eiciunt non placando omnesque temptationes aduersitatesque eius uincunt orando non ipsam, sed deum suum aduersus ipsam. Non enim aliquem uincit aut subiugat nisi societate peccati. In eius ergo nomine uincitur qui hominem assumpsit egitque sine peccato, ut in ipso sacerdote ac sacrificio fieret remissio peccatorum, idest per mediatorem dei et hominum, hominem Christum Ihesum, per quem facta peccatorum purgatione reconciliamur deo. Non enim //fol. 19vb// nisi peccatis homines separantur a deo. ${ }^{142}$

IDenique ipse Porfirius dicit diuinis oraculis fuisse responsum nos non purgari lune theletis atque solis, ${ }^{143}$ sed sola principia nos purgare posse. Dicit autem principia tanquam Platonicus ${ }^{144}$ deum patrem et deum filium quem Grece appellat ${ }^{145}$ patricum noym, ${ }^{146}$ idest paternum intellectum uel paternam mentem. De spiritu autem sancto aut nichil aut non aperte aliquid dicit, quamuis quem alium dicat horum medium non intelligo. Si enim terciam ${ }^{147}$ anime uniuersalis naturam uellet intelligi, ${ }^{148}$ sicut Plotinus, ubi de tribus principalibus substantiis disputat, ${ }^{149}$ non utique diceret horum medium, idest patris et filii medium. Postponit quippe Plotinus anime naturam paterno intellectui, iste autem cum dicit medium, non postponit, sed

140. Сiu. 10.21 (CCSL 47: 295.24-30); 'bibens' cod.] libens Aug.

141. Сіи. 10.21 (CCSL 47: 295.31-37).

142. Сіи. 10.22 (CCSL 47: 296.1-10); 'inimicamque' cod.] inimicam contrariamque Aug.

143. Сiu. 10.23 (CCSL 47: 296.1-2).

144. Сіи. 10.23 (CCSL 47: 296.8-9).

145. Сіи. 10.23 (CCSL 47: 296.10).

146. Сіи. 10.28 (CCSL 47: 303.18-21): "Ignorantiam certe et propter eam multa uitia per nullas

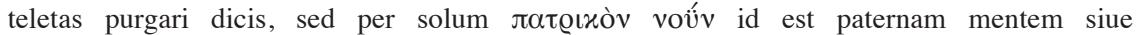
intellectum, qui paternae est conscius uoluntatis."; ciu. 10.23 (CCSL 47: 296.8-11): "Quae autem dicat esse principia tanquam Platonicus, nouimus. Dicit enim Deum Patrem et Deum Filium, quem Graece appellat paternum intellectum uel paternam mentem."

147. Сіи. 10.23 (CCSL 47: 296.11-14).

148. Сiu. 10.23 (CCSL 47: 296.15).

149. Сіи. 10.23 (CCSL 47: 296.14-15). 
interponit. Et nimirum hoc dixit ut potuit siue ut uoluit quod nos spiritum sanctum nec patris tantum nec filii tantum, sed utriusque spiritum dicimus. Liberis enim uerbis loquuntur philosophi nec in rebus ad intelligendum difficillimis offensionem religiosarum aurium pertimescunt. Nobis autem ad certam regulam loqui fas est, ne uerborum licentia etiam de rebus que hiis significantur impiam gignat opinionem. ${ }^{150}$ Verum itaque dictum est non purgari hominem nisi principio, quamuis apud eos principia dicta sint pluraliter. ${ }^{151}$ Nos autem non dicimus patrem et filium duo esse principia, sicut nec duos deos. ${ }^{152}$ Sed subditus Porfirius inuidis potestatibus de quibus et erubescebat et eas libere redarguere formidabat, noluit intelligere dominum Ihesum Christum esse principium cuius incarnatione purgamur, ${ }^{153}$ despiciens eum in carne. ${ }^{154}$ Sed bonus et uerus mediator ostendit peccatum non carnis substantiam uel naturam esse malum qui cum anima hominis et suscipi sine peccato potuit et haberi et morte deponi et in melius resurrectione mutari nec ipsam mortem quamuis esset pena peccati quam tamen pro nobis sine peccato ipse persoluit peccando esse uitandam, sed potius //fol. 20ral/ si facultas detur pro iusticia esse preferendam. Ideo enim soluere potuit moriendo peccata quia mortuus est et non pro peccato. Hunc ille Platonicus non cognouit esse principium, nam cognosceret purgatorium. Neque enim caro principium est aut anima humana, sed uerbum per quod facta sunt omnia. Non ergo caro per seipsam mundat, sed per uerbum a quo suscepta est. ${ }^{155}$

JConfitetur autem Porfirius errare homines in theurgica disciplina et quam plurimos fallere per cecam insipientemque scientiam atque esse certissimum errorem agendo et supplicando ad principes angelos decurrer ${ }^{156}$ et in specialem animam sine theurgicis artibus et sine teletis ${ }^{157}$ continentie uirtute purgari. ${ }^{158}$ Dicit etiam aliquando quod thelete non post mortem eleuent animam. ${ }^{159}$ Ignorantiam quoque et propter ea multa uitia per nullas theletas purgari dicit, sed per solum patricum noym. ${ }^{160}$

150. Сіи. 10.23 (CCSL 47: 296.16-297.26).

151. Сіи. 10.24 (CCSL 47: 297.9-11).

152. Cf. сіи. 10.24 (CCSL 47: 297.1-5): "Nos itaque non dicimus duo uel tria principia, cum de deo loquimur, sicut nec duos deos uel tres nobis licitum est dicere, quamuis de unoquoque loquentes, uel de patre uel de filio uel de ppiritu sancto, etiam singulum quemque deum esse fateamur."

153. Сіи. 10.24 (CCSL 47: 297.12-15).

154. Сf. сіи. 10.24 (CCSL 47: 297.15-22).

155. Сiu. 10.24 (CCSL 47: 297.22-34).

156. Сiu. 10.27 (CCSL 47: 303.67-70).

157. Сiu. 10.28 (CCSL 47: 303.6-7); in specialem cod.] etiam spiritualem Aug.

158. Сіи. 10.28 (CCSL 47: 303.8).

159. Сіи. 10.28 (CCSL 47: 303.8-9).

160. Сіи. 10.28 (CCSL 47: 303.18-19); quoque cod.] certe Aug.; ea cod.] eam Aug. 
IConfi tur etiam dei gratiam ubi dicit ad deum per uirtutem intelligentie peruenire paucis esse concessum. ${ }^{161} \mathrm{Cum}$ enim dicit concessum, non hominis sufficientiam $^{162}$ sed dei gratiam profitetur. Vtitur etiam hoc uerbo apercius ubi Platonis sententiam sequens nec ipse dubitat in hac uita hominem nullomodo ad perfectionem peruenire secundum tamen intellectum uiuentibus omne quod deest prouidentia dei et gratia post hanc uitam posse compleri ${ }^{163}$ Discernit autem a demonibus angelos, aeria loca esse demonum, etherea uel empirea angelorum, et tamen pessime admonet utendum alicuius demonis amicitia quo subuectante uel paululum a terra possit eleuari quisque post mortem. Aliam uero uiam esse perhibet ad angelorum superna consortia cauendam tamen demonum societatem aperta quodammodo confessione testatur, ubi dicit animam post mortem luendo penas cultum demonum a quibus circumueniebatur horrescere ipsamque theurgian quam uelut artem conciliatricem angelorum //fol.20rb// deorumque commendat apud tales agere potestates negare non potuit que uel ipse inuideant purgationi anime uel artibus seruiant inuidorum querelam de hac re nescio cuius depromens: Conqueritur, inquit, uir in Caldea bonus purgande anime magno in molimine frustratos sibi esse successus cum uir ad eadem potens tactus inuidia adiuratas sacris precibus potentias alligasset, ne postulata concederent. Ergo et ligauit ille, inquit, et iste non soluit. Quo indicio dixit apparere theurgiam esse tam boni conficiendi quam mali et apud homines disciplinam; pati etiam deos et ad illas etiam perturbationes deduci quas communiter demonibus et hominibus Apuleius attribuit. ${ }^{164}$

ISic itaque Porfirius quandam quasi purgationem anime per theurgian cunctanter tamen et pudibunda quodammodo disputatione promittit. Reuersionem uero ad deum prestare cuiquam negat ut uideas eum inter nitium sacrilege curiositatis et philosophie professionem sentenciis altercantibus fluctuare. Nunc enim hanc artem tanquam fallacem et in ipsa actione periculosam et legibus prohibitam cauendam monet. Nunc autem eius laudatoribus cedens utilem dicit esse mundande parti anime non quidem intellectuali qua rerum intelligibilium percipitur ueritas nullas habentium similitudines corporum, sed spirituali qua corporalium rerum capiuntur ymagines. Hanc enim dicit per quasdam consecrationes theurgicas quas theletas uocant idoneam fieri atque aptam susceptioni spirituum et angelorum et ad uidendos deos, ex quibus theurgicis theletis fatetur intellectuali anime nichil purgationis accedere quod eam faciat idoneam ad uidendum deum suum et per-

161. Сіи. 10.29 (CCSL 47: 304.11-13).

162. Сіи. 10.29 (CCSL 47: 304.14-15).

163. Сіи. 10.29 (CCSL 47: 304.16-20).

164. Сіи. 10.9 (CCSL 47: 282.37-283.58). 
spicienda ea que uere sunt. ${ }^{165}$ Denique ipsam animam rationalem uel sicut amat dicere intellectualem in sua posse dicit euadere, etiam si quod eius spirituale est nulla teurgica fuerit arte purgatum. Porro autem thurgico purgari hactenus ut non ex hoc ad immortalitatem eternitatemque. ${ }^{166}$

IQuidam autem discernunt inter theurgian //fol. 20va// et magian et goethian, dicentes illicitis artibus deditos alios dampnabiles alios esse laudabiles. Primis duo vitiam nomina deputant, secundis primum, idest nomen theurgice artis, idest purgatiue. ${ }^{167}$ Sed reuera utrique ritibus fallacibus demonum obstricti sunt sub nominibus angelorum. ${ }^{168}$

165. Сіи. 10.9 (CCSL 47: 281.13-282.30)

166. Сіи. 10.9 (CCSL 47: 282.32-37)

167. Cf. сіи. 10.9 (CCSL 47: 281.3-11).

168. Сіи. 10.9 (CCSL 47: 281.11-12); sed reuera cod.] cum sint Aug. 